\title{
Representativeness and climatology of carbon monoxide and ozone at the global GAW station Mt. Kenya in equatorial Africa
}

\author{
S. Henne ${ }^{1}$, J. Klausen ${ }^{1}$, W. Junkermann ${ }^{2}$, J. M. Kariuki ${ }^{3}$, J. O. Aseyo ${ }^{3}$, and B. Buchmann ${ }^{1}$ \\ ${ }^{1}$ Empa, Swiss Federal Laboratories for Materials Testing and Research, Dübendorf, Switzerland \\ ${ }^{2}$ Forschungszentrum Karlsruhe, Institut für Meteorologie und Klimaforschung IFU, Garmisch-Partenkirchen, Germany \\ ${ }^{3}$ Kenyan Meteorological Department, Nairobi, Kenya
}

Received: 12 October 2007 - Published in Atmos. Chem. Phys. Discuss.: 10 December 2007

Revised: 4 April 2008 - Accepted: 19 May 2008 - Published: 23 June 2008

\begin{abstract}
The tropics strongly influence the global atmospheric chemistry budget. However, continuous in-situ observations of trace gases are rare especially in equatorial Africa. The WMO Global Atmosphere Watch (GAW) programme aimed to close this gap with the installation of the Mt. Kenya (MKN) baseline station. Here, the first continuous measurements of carbon monoxide $(\mathrm{CO})$ and ozone $\left(\mathrm{O}_{3}\right)$ at this site covering the period June 2002 to June 2006 are presented. The representativeness of the site was investigated by means of statistical data analysis, air mass trajectory clustering, interpretation of biomass burning variability and evaluation of $\mathrm{O}_{3}-\mathrm{CO}$ relationships. Because of its location in eastern equatorial Africa, the site was rarely directly influenced by biomass burning emissions, making it suitable for background observations. Located at $3678 \mathrm{~m}$ above sea level the night-time (21:00-04:00 UTC) measurements of $\mathrm{CO}$ and $\mathrm{O}_{3}$ were in general representative of the free troposphere, while day-time measurements were influenced by atmospheric boundary layer air. Increased night-time concentrations were observed in $25 \%$ of all nights and associated with residual layers of increased $\mathrm{CO}$ and water vapour in the free troposphere. Six representative flow regimes towards Mt. Kenya were determined: eastern Africa (21\% of the time), Arabian Peninsula and Pakistan (16\%), northern Africa free tropospheric $(6 \%)$, northern Indian Ocean and India (17\%), south-eastern Africa (18\%) and southern India Ocean $(21 \%)$ flow regimes. The seasonal alternation of these flow regimes was determined by the monsoon circulation and caused a distinct semi-annual cycle of $\mathrm{CO}$ with maxima during February (primary) and August (secondary, annually variable) and with minima in April (primary) and November (secondary, annually variable). $\mathrm{O}_{3}$ showed a weaker annual cycle with a minimum in November and a broad sum-
\end{abstract}

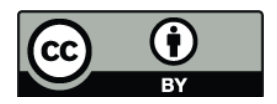

Correspondence to: S. Henne (stephan.henne@empa.ch) mer maximum. Inter-annual variations were explained with differences in southern African biomass burning and transport towards MKN. Although biomass burning had little direct influence on the measurements at MKN it introduces inter-annual variability in the background concentrations of the southern hemisphere that subsequently reaches Kenya. The measurements at MKN were representative of air masses with little photochemical activity as indicated by weak $\mathrm{O}_{3}$ $\mathrm{CO}$ correlations, underlining the baseline character of the site. Inter-comparison of $\mathrm{O}_{3}$ at $\mathrm{MKN}$ with sounding data from Nairobi revealed a positive offset of the sounding data, most likely due to additional photochemical production of $\mathrm{O}_{3}$ in the Nairobi city plume. Future extensions of the measurement programme will provide better understanding of the atmospheric chemistry of this globally important region.

\section{Introduction}

Carbon monoxide (CO) and ozone $\left(\mathrm{O}_{3}\right)$ are two key species in the photochemical system of the troposphere. Carbon monoxide controls the concentrations and distributions of atmospheric oxidants, such as $\mathrm{O}_{3}$, hydroperoxy $\left(\mathrm{HO}_{2}\right)$ and hydroxyl $(\mathrm{OH})$ radicals. About $70 \%$ of $\mathrm{OH}$ radicals in the background atmosphere react with $\mathrm{CO}$ (Crutzen and Andreae, 1990). Therefore, the concentration of CO largely determines the availability of $\mathrm{OH}$ radicals. The $\mathrm{OH}$ radical is the main "cleansing agent" of the atmosphere, removing air pollutants or greenhouse gases, the most prominent being methane $\left(\mathrm{CH}_{4}\right)$, from the atmosphere. An increase in $\mathrm{CO}$ is expected to decrease $\mathrm{OH}$ and hence to increase the lifetime and abundance of these gases. $\mathrm{CO}$ itself has a lifetime of weeks to months and is therefore a useful tracer for combustion of biomass and fossil fuels (e.g. Fishman and Seiler, 1983; Parrish et al., 1993). CO is emitted from fossil fuel and biomass burning at low temperatures and low oxygen conditions. Up to $45 \%$ of the total atmospheric CO

Published by Copernicus Publications on behalf of the European Geosciences Union. 
source results from oxidation of methane and other organics in the atmosphere (Scholes et al., 2003). Global emissions of $\mathrm{CO}$ from biomass burning were estimated by Andreae and Merlet (2001) to be about $690 \mathrm{Tg} \mathrm{CO} \mathrm{yr}^{-1}$, whereas earlier studies indicated large uncertainties (280-1190 $\mathrm{Tg} \mathrm{CO} \mathrm{yr}^{-1}$ ) (Crutzen and Andreae, 1990). This accounts for almost half of the global annual primary CO emissions (IPCC, 2001; Crutzen and Andreae, 1990). Tropical forest and savanna fires comprise about $50 \%$ of these emissions (Andreae and Merlet, 2001) and can therefore significantly lower the oxidative capacity of the troposphere and increase lifetimes of other, climate relevant, gases (Crutzen and Andreae, 1990).

Tropospheric $\mathrm{O}_{3}$ acts both to control the oxidizing capacity of the atmosphere, by photolysis followed by reaction with water vapor $\left(\mathrm{H}_{2} \mathrm{O}\right)$ forming $\mathrm{OH}$ radicals, and as a greenhouse gas (Levy, 1971; Chameides and Walker, 1973). Ozone is produced in the troposphere by the photochemical oxidation of hydrocarbons, $\mathrm{CH}_{4}$, and $\mathrm{CO}$ in the presence of nitrogen oxides $\left(\mathrm{NO}_{\mathrm{x}}=\mathrm{NO}+\mathrm{NO}_{2}\right)($ Chameides and Walker, 1973; Crutzen, 1974; Fishman et al., 1979) and is transported downwards from the stratosphere (Lelieveld and Dentener, 2000, and references therein). Most of the oxidation of longlived, reduced gases by $\mathrm{OH}$ takes place in the tropics, where high UV and humidity promote the formation of $\mathrm{OH}$ from the photolysis of $\mathrm{O}_{3}$ (Logan et al., 1981; Thompson, 1992), which on the one hand represents an important $\mathrm{O}_{3}$ sink especially over the remote tropical oceans. On the other hand, emissions of $\mathrm{O}_{3}$ precursors in the tropics have a large $\mathrm{O}_{3}$ production potential because deep convection can quickly transport surface emissions to the middle and upper troposphere where their lifetimes are increased due to dilution with unpolluted background air and lack of surface deposition (e.g. Pickering et al., 1995). In addition, lightning-produced $\mathrm{NO}_{\mathrm{x}}$ increases $\mathrm{O}_{3}$ production. This mechanism has been called "mix then cook" by Chatfield and Delany (1990). However, surface emissions of $\mathrm{NO}_{\mathrm{x}}$ in tropical countries (especially India and Southeast Asia) are small due to the dominance of biofuel usage and the associated low temperature combustion, $\mathrm{O}_{3}$ production is often limited (Lelieveld et al., 2001). By means of global chemistry modeling, the contribution of biomass burning to the tropospheric $\mathrm{O}_{3}$ burden was estimated to be $10-15 \%$ in the tropics and $<10 \%$ in the extratropics (Lelieveld and Dentener, 2000). The contribution of African biomass burning emissions to $\mathrm{O}_{3}$ mixing ratios reaches $\sim 24 \%$ in the African boundary layer (Marufu et al., 2000 ) and $\sim 14 \%$ for the tropospheric column over Africa (Lelieveld and Dentener, 2000), while the contribution to global tropospheric $\mathrm{O}_{3}$ was estimated to be $3.2 \%$ (Marufu et al., 2000) and 2.4\% (Aghedo et al., 2007). Seventy percent of the $\mathrm{O}_{3}$ produced from African emissions is found off the continent with the largest influence on South America (Aghedo et al., 2007).

Despite these large-scale impacts, atmospheric chemistry over equatorial Africa remains poorly documented. A number of field campaigns were conducted in tropical and south- ern Africa, mostly focusing on emissions from biomass burning (e.g. SAFARI 1992 Lindesay et al., 1996; TRACE-A 1992 Fishman et al., 1996; SAFARI 2000 Swap et al., 2003). Furthermore, the INDOEX experiment focused on pollution outflow from India over the Indian Ocean and towards eastern Africa during winter monsoon conditions (Lelieveld et al., 2001) and more recently the AMMA research project is investigating the West African monsoon and its influences on the physical, chemical and biological environment (Redelsperger et al., 2006). In addition to these campaign-based measurements, long-term observations of the $\mathrm{O}_{3}$ profile over Africa are currently being made within the SHADOZ programme (Thompson et al., 2004) and within the MOZAIC programme (Marenco et al., 1998) onboard commercial aircraft starting from and landing at several tropical African airports (Sauvage et al., 2005). Nevertheless, Thompson et al. (2004) argue that weekly observations of $\mathrm{O}_{3}$ may not be robust enough for trend analysis in the Tropics due to the strong variability caused by deep convection. For CO, weekly flask sampling data from the tropical African region are available from the Seychelles, Ascension Island and Mt. Kenya through the NOAA ESRL programme (Novelli et al., 2003). Finally, satellite observations of both $\mathrm{O}_{3}$ and $\mathrm{CO}$ are available (e.g. Watson et al., 1990; Edwards et al., 2006b). However, so far these don't provide an adequate vertical profile and might be subject to large uncertainties (e.g. Newchurch et al., 2001; Martin et al., 2002).

Up to now, no long-term continuous observations of the composition of the tropical atmosphere over Africa are available. Here we present the first continuous observations of $\mathrm{CO}$ and $\mathrm{O}_{3}$ in tropical Africa as measured at the high altitude Global Atmosphere Watch (GAW) station Mt. Kenya (MKN) in eastern Africa. We focus on the question of representativeness of the station in terms of vertical atmospheric layers and horizontal regions of influence, to discuss the station's suitability to serve as a baseline site for eastern tropical Africa. We describe the chemical climatology of the site as dependent on air mass origin and discuss inter-annual variability in connection with the southern African biomass burning season. $\mathrm{O}_{3}-\mathrm{CO}$ relationships are investigated to derive further insight into the photochemical state of the free troposphere (FT) over Kenya. Measurement results are compared to other existing measurements for this region and satellite-retrieved $\mathrm{CO}$ concentrations. In the future, these long-term continuous observations are expected to be used for trend analysis, satellite and model evaluation and climatological validation of event type data.

\section{Methods}

\subsection{Measurement site}

The MKN Global Atmosphere Watch (GAW) (World Meteorological Organization, 2007) station $\left(37.297^{\circ} \mathrm{E}, 0.062^{\circ} \mathrm{S}\right.$, 
$3678 \mathrm{~m}$ a.s.1.; $660 \mathrm{hPa}$ pressure equivalent and $\sim 1700 \mathrm{~m}$ above the foot of the mountain) is situated on the northwestern slope of Mt. Kenya. Down-slope of the station grassland species (Festuca pilgrim, Carex spp.) and shrubs (Artemisia afra, Protea, Helichrysum) are the dominating vegetation. Up-slope grassland species and sparse lobelia (Lobelia telekii, Lobelia keniensis) are the only vegetation present. The timberline is situated about $5 \mathrm{~km}$ to the northwest of and $500 \mathrm{~m}$ below the site. As part of the Mt. Kenya National Park the whole mountain area is protected and there are no local anthropogenic emissions, making the site suitable for continuous observations of the background free tropospheric composition. The station consists of two containers with a flat walk-on roof, where the air inlet and meteorological instrumentation is mounted. The containers are presently not air conditioned and undergo temperature variations from $\sim 10^{\circ} \mathrm{C}$ in the morning to $\sim 20^{\circ} \mathrm{C}$ in the afternoon. All data in this manuscript are reported in UTC, while the local time at the site is UTC +3 . A detailed description of the measurement site, its meteorological instrumentation and the local meteorology can be found in Henne et al. (2008).

\subsection{Instrumentation and data quality control}

A rain and snow protected air inlet system is mounted $4.5 \mathrm{~m}$ above ground and is connected to a glass manifold (length $3 \mathrm{~m}$, diameter $5 \mathrm{~cm}$ ) to which individual instruments are connected. The manifold is permanently flushed by a high volume pump. Residence times were estimated to be below $10 \mathrm{~s}$.

$\mathrm{CO}$ was measured using commercial non-dispersive infrared absorbance (NDIR) gas filter correlation technique (Thermo Electron Corporation TEI 48C TL). Sample air was taken from the glass manifold through a $1.5 \mathrm{~m}, 4 \mathrm{~mm}$ diameter teflon tubing at a flow rate of $1 \mathrm{lpm}$. A $47 \mathrm{~mm}$ teflon filter (5-6 micron) was installed before the sample gas inlet and was regularly exchanged. To reduce the interference from water vapor, a Nafion dryer (PERMAPURE PD-50-24") was installed in the sampling line, operating in reverse flux mode using a critical orifice, similar to that described in Nédélec et al. (2003). Due to the container temperature changes the NDIR showed strong zero drift. Therefore, zero air measurements were performed every two $\mathrm{h}$ for $20 \mathrm{~min}$. Zero air was generated using a custom built system consisting of a rubin gel cartridge, a SOFNOCAT 423 (Molecular Products Ltd) cartridge, and inlet and outlet filters, with a $\mathrm{CO}$ scrubbing efficiency of $99.9 \%$ for CO levels up to $1 \%$. Since 2004, span gas checks have been performed every two hours for $10 \mathrm{~min}$. A higher concentration laboratory standard (traced back to WMO-2000 CO scale by GAW World Calibration Center (WCC), Empa) was diluted with zero air (using Bronckhorst mass flow controllers) and fed into the span gas inlet. In addition, manual span gas checks directly using $1 \mathrm{ppm}$ laboratory standards (WMO-2000) were performed by the station operators once per month.
All measurements were subject to plausibility checks using time series plots and a semi-automated software tool for data flagging and data storage in a SQL database. Due to drift, $\mathrm{CO}$ zero conditions during ambient air sampling were estimated from zero air measurements using local regression models (e.g. Loader, 1999). A span correction was applied in a similar way. The combined uncertainty of every individual 1-min CO measurement was then determined from the contributions of the uncertainty of the CO analyzer, the uncertainty of the zero correction and the uncertainty of the span correction. The estimated random part of the instruments uncertainty (precision) was $8 \mathrm{ppb}$ for $5 \mathrm{~min}$ averages and the non-random part of the uncertainty (accuracy) was $\sqrt{7^{2}+0.006^{2} \cdot C^{2}} \mathrm{ppb}$, where $C$ is the measured concentration. Data was aggregated to 1-h intervals. The enlarged uncertainty of the 1-h data due to missing values was considered following ISO11222 (ISO, 2002). The average expanded uncertainty of the hourly CO measurements was $16 \mathrm{ppb}$ (95\% confidence level). We compared our $\mathrm{CO}$ measurements with canister samples that were taken weekly from 2003-12-01 to 200608-02 during station visits (10 UTC) for NOAA ESRL (former CMDL) (Novelli et al., 1998b,a, 2003). The relationship between continuous measurements and canister samples was $[\mathrm{CO}]_{\text {cont }}=0.96( \pm 0.11)[\mathrm{CO}]_{\text {canister }}-2.1( \pm 11.3)$, $r=0.79, n=27$. The comparison suggests no significant deviation between both measurements, but it is difficult to draw strong conclusions from this comparison, since the sample size was small and continuous and flask measurements were not obtained from the exact same volume of air.

$\mathrm{O}_{3}$ was measured using a commercial UV absorption $(254 \mathrm{~nm})$ technique (Thermo Electron Corporation TEI 49, SN: 51959-290). Sample air was taken from the glass manifold through a $1.5 \mathrm{~m}, 4 \mathrm{~mm}$ diameter teflon tubing at a flow rate of $2 \mathrm{lpm}$. A $47 \mathrm{~mm}$ teflon filter (5-6 micron) was installed before the sample gas inlet and was regularly replaced. The uncertainty of the $\mathrm{O}_{3}$ measurements was assessed following the analysis of Klausen et al. (2003), taking audit inter-comparisons with a Standard Reference Photometer into account. Aggregates and their uncertainties were derived similar to $\mathrm{CO}$. The average combined expanded uncertainty of the hourly $\mathrm{O}_{3}$ measurements was $3 \mathrm{ppb}$ (95\% confidence level).

For both instruments standard operation procedures (SOP) were developed and followed closely by the station operators. The station was audited by GAW WCC for $\mathrm{O}_{3}$ and $\mathrm{CO}$ in February 2002, February 2005 and February 2006, and measurements were traced back to the GAW Reference Standard (Zellweger et al., 2002, 2005; Klausen et al., 2006). The data discussed here cover the period from June 2002 to June 2006. Due mostly to frequent interruptions in the power supply at MKN, the data coverage for the 4-year period was only 52 and $49 \%$ for $\mathrm{CO}$ and $\mathrm{O}_{3}$, respectively. All time stamps of the hourly data refer to the end of the sampling period. Fourhourly aggregates were derived for use with air mass back 
trajectories, such that the arrival time of the trajectory fell in the center of the 4-h aggregation period.

\subsection{Trajectory calculations}

Kinematic backward air mass trajectories were calculated on 6-hourly ECMWF analysis fields (T511L60 before February 2006 and T799L91 afterwards) interlaced with 6-hourly forecast fields with $1 \times 1^{\circ}$ horizontal resolution using the trajectory model FLEXTRA (Stohl et al., 1995; Stohl and Seibert, 1998). Trajectories were initialized every $4 \mathrm{~h}(02: 00,06: 00$, 10:00, 14:00, 18:00, 22:00 UTC) at station altitude, which corresponds to $1829 \mathrm{~m}$ above model ground, and were followed 10 days backward in time. Since Mt. Kenya is an isolated mountain rising high above its surroundings and the following analysis focuses on long range transport influences, we are confident that the regional scale, horizontal wind speed at the station is best represented by the chosen arrival altitude. The trajectory position was stored every $3 \mathrm{~h}$. Individual air mass trajectories might be subject to calculation errors that arise from uncertainties in the utilized wind analysis or forecast fields, truncation errors due to finite-difference integration scheme or temporal and spatial interpolation errors (Stohl, 1998). Furthermore, subgrid scale processes like convection and turbulent diffusion are not represented by individual trajectories. To compensate for part of this uncertainty, in addition to the central reference trajectory, 6 uncertainty trajectories were initialized equidistantly spaced on a circle of $0.5^{\circ}$ radius around the site at the same altitude above model ground.

\subsection{Trajectory clustering}

Several different approaches to air mass trajectory clustering to categorize air mass influence on chemical composition measurements are described in the scientific literature (e.g. Moody and Galloway, 1988; Harris and Kahl, 1990; Dorling et al., 1992a,b). Following the approach of Dorling et al. (1992a), we used a combined clustering method that in a first step applied Ward's hierarchical clustering method (Ward, 1963) to determine the number of clusters to retain and in a second step used k-medoids clustering (e.g. Kaufman and Rousseeuw, 1990) to assure the compactness of the derived clusters. With hierarchical clustering the number of clusters to be retained can be determined semi-objectively during the amalgamation process. The relative increase in total withincluster sum of squared distances for each reduction of the number of clusters will be large when two relatively different clusters are joined. Therefore, the number of clusters should be kept large enough so that no large relative increase occurs. A threshold value of $5 \%$ was chosen in this study similar to Dorling et al. (1992a,b) and Brankov et al. (1998).

All 3-hourly trajectory positions were used (i.e. a total of 80 points per trajectory) as clustering variables. The sensitivity of the clustering procedure to the choice of the distance measure between trajectory pairs was tested by applying different distance measures (2-D-Euclidean, normalized 2-D and 3-D-Euclidean, 2-D-spherical, 2-D-spherical plus scaled vertical distance). All distance measures yielded similar results, however we preferred the two-dimensional spherical distance measure to avoid erroneous behavior when trajectory pairs would lie on either side of the date line. Since no additional weighting was applied to these variables, strong relative differences in trajectory location close to the arrival will cause less absolute distance between two trajectories than differences at their origin. This clustering method thus focuses on differences in the air mass origin and not on differences in the local approach to the site. The clustering was applied to reference and uncertainty trajectories when nighttime (22:00 - 02:00 UTC, see Sect. 3.2) $\mathrm{CO}$ and $\mathrm{O}_{3}$ measurements were available. A total of 11179 trajectories were taken into account in the final clustering.

All clustering calculations were performed with the statistics software package R version 2.2.1 (R Development Core Team, 2005). Functions for hierarchical and k-means clustering can be found in the stats package, while k-medoids clustering is available in the cluster package, which implements the algorithms described in Kaufman and Rousseeuw (1990).

\section{$2.5 \mathrm{O}_{3}-\mathrm{CO}$ correlations}

The $\mathrm{O}_{3}-\mathrm{CO}$ relationship has been used to estimate the $\mathrm{O}_{3}$ export of certain $\mathrm{O}_{3}$ precursor source regions (Fishman and Seiler, 1983; Parrish et al., 1993). Both CO and $\mathrm{O}_{3}$ measurements are subject to uncertainty. Therefore, we used a regression model that takes these uncertainties in both variables into account (Press et al., 1992) weighting individual data points with the inverse of their associated uncertainty. Parrish et al. (1998) noted that using a method including measurement uncertainties in both variables instead of ordinary least squares with errors in the y variable only yielded steeper regression slopes for the $\mathrm{O}_{3}$-CO relationship. We compared the Press et al. (1992) method with reduced major axis (RMA) and ordinary least square regression. Slopes were usually largest for the Press et al. (1992) model, followed by RMA and ordinary least squares. However, differences were small for cases with large correlation coefficients.

\section{Results and discussion}

\subsection{Pollution events}

As described above, the local environment of the MKN site is mostly free of anthropogenic emissions. However, infrequent, small wildfires occur within the forest and bush belt of the mountain. These fires emit CO close to the measurement site and therefore can be detected as large peaks in the measured data that disturb the atmospheric background measurements. In order to remove such events from the 
climatological analysis the measurements were filtered by applying an iterative moving standard deviation filter to $\mathrm{CO}$. Using a window width of 14 days, moving average and standard deviation of $\mathrm{CO}$ were computed. Data points outside of three standard deviations of the mean were then removed and the procedure repeated until no new outliers were detected.

If more than two outliers (more than $2 \mathrm{~h}$ ) were detected on an individual day this day was flagged as a pollution event. Nine different pollution events were detected with this method distributed over 16 of a total of 780 days (2\%; see also supplementary material, http://www.atmos-chem-phys. net/8/3119/2008/acp-8-3119-2008-supplement.pdf).

The origin of two major events could be traced back to local fire observations made by the station operators, one event could be identified as transport of an aged biomass burning plume (see Sect. 3.6), while the causes of the minor events, with a length of 1-2 days, could not be identified and are thought to be of local origin. All detected events were excluded from the following climatological analysis of the data.

\subsection{Diurnal cycle}

Not only local sources and sinks but also the influence of variable atmospheric boundary layer (ABL) depth might cause strong diurnal variations in atmospheric trace gases. Especially at high altitude sites the question arises as to which atmospheric layer the measurements are representative. Henne et al. (2008) observed a frequent development of slope wind circulations at MKN and turbulent vertical transport of boundary layer air towards MKN during daytime. These transport processes manifest themselves in a pronounced diurnal cycle of $\mathrm{CO}$ mixing ratios (Fig. 1). Shortly after sunrise (04:00 UTC) CO starts to rise as a result of advection of more polluted $\mathrm{ABL}$ air and reaches a maximum between 11:00 and 13:00 UTC. The average diurnal amplitude was $15 \mathrm{ppb}$. This pattern recurs during all months of the the year, with an increased amplitude (25-30 ppb) during July and September.

For $\mathrm{O}_{3}$ the diurnal cycle is almost the inverse of that of $\mathrm{CO}$ with a day-time minimum and night-time maximum and an average amplitude of $4 \mathrm{ppb}$. The amplitude of the $\mathrm{O}_{3}$ diurnal cycle was larger in the months of December and January. The day-time minimum of $\mathrm{O}_{3}$ is thought to have two different causes. On the one hand, due to surface dry deposition, $\mathrm{O}_{3}$ mixing ratios in the ABL over Kenya are usually smaller than those in the FT (Thompson et al., 2004), see also Sect. 3.7.2. Advection of $\mathrm{ABL}$ air would therefore decrease $\mathrm{O}_{3}$ mixing ratios at $\mathrm{MKN}$. On the other hand, $\mathrm{O}_{3}$ might also be photochemically destroyed in the FT under low nitrogen oxides $\left(\mathrm{NO}_{\mathrm{x}}\right)$ conditions, which are likely for the clean East African area (Klonecki and Levy, 1997). The latter process would also explain the time shift between the $\mathrm{O}_{3}$ afternoon minimum and the $\mathrm{CO}$ maximum by about $2 \mathrm{~h}$. While $\mathrm{CO}$ concentrations slowly decreased in the late afternoon because up-slope winds weakened, $\mathrm{O}_{3}$ continued to decrease as a re-
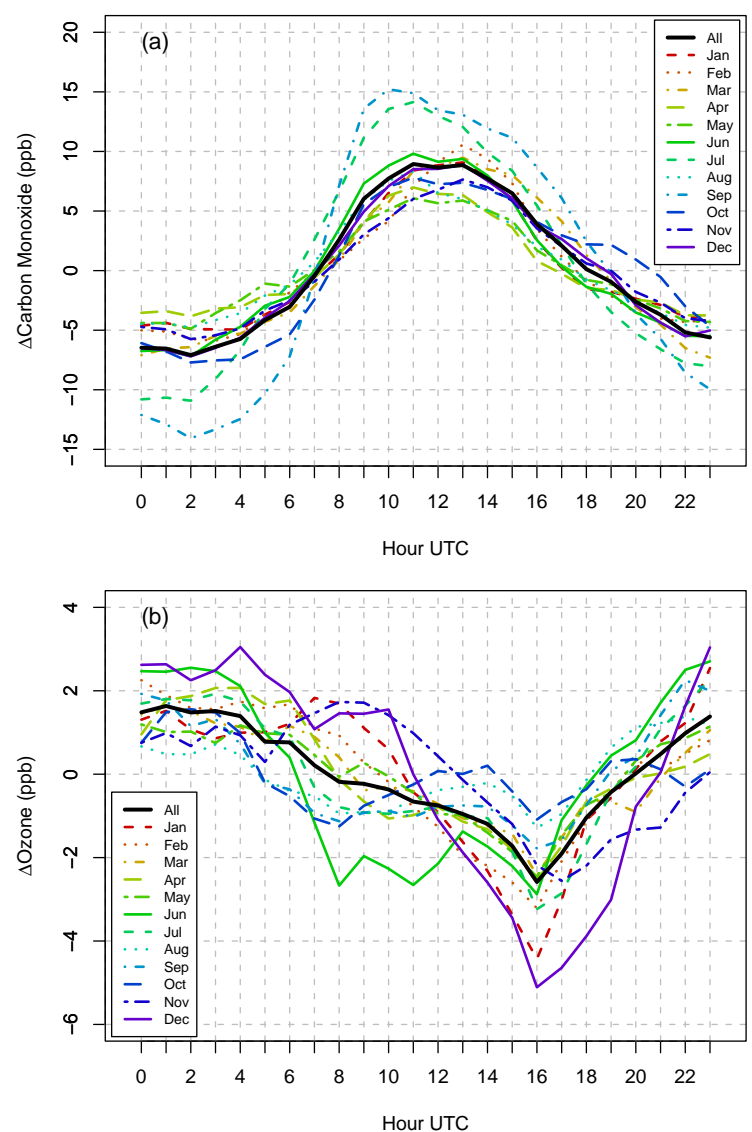

Fig. 1. Diurnal cycle of (a) carbon monoxide and (b) ozone. The black line represents the annual mean, while coloured lines refer to individual months. Note that the diurnal mean was subtracted before aggregation.

sult of continued photochemical destruction taking place in both ABL and free tropospheric air; the latter process has to be viewed integrated over all day-time hours.

The diurnal cycle was expected to be different for days with and without development of thermally-induced up-slope flow disturbing the free tropospheric conditions at the site. In order to distinguish between these two categories two independent filters based on the course of the local wind (the possible driver for ABL air influence) and specific humidity, $\mathrm{q}$, (used as indicator of ABL air influence) were developed by Henne et al. (2008). For the first criterion, days were categorised as synoptically or thermally influenced days. From a total of 548 days with complete data coverage for all necessary meteorological parameters, 90 were selected by the wind criterion as showing no pronounced up-/downslope pattern (syn) and 458 days as thermally (therm) influenced. Using a second independent criterion, we identified days that showed a significantly (two-sample t-test, $p<0.05)$ higher day-time $(13: 00-16: 00$ UTC) than nighttime (01:00-04:00 UTC) specific humidity. This second 

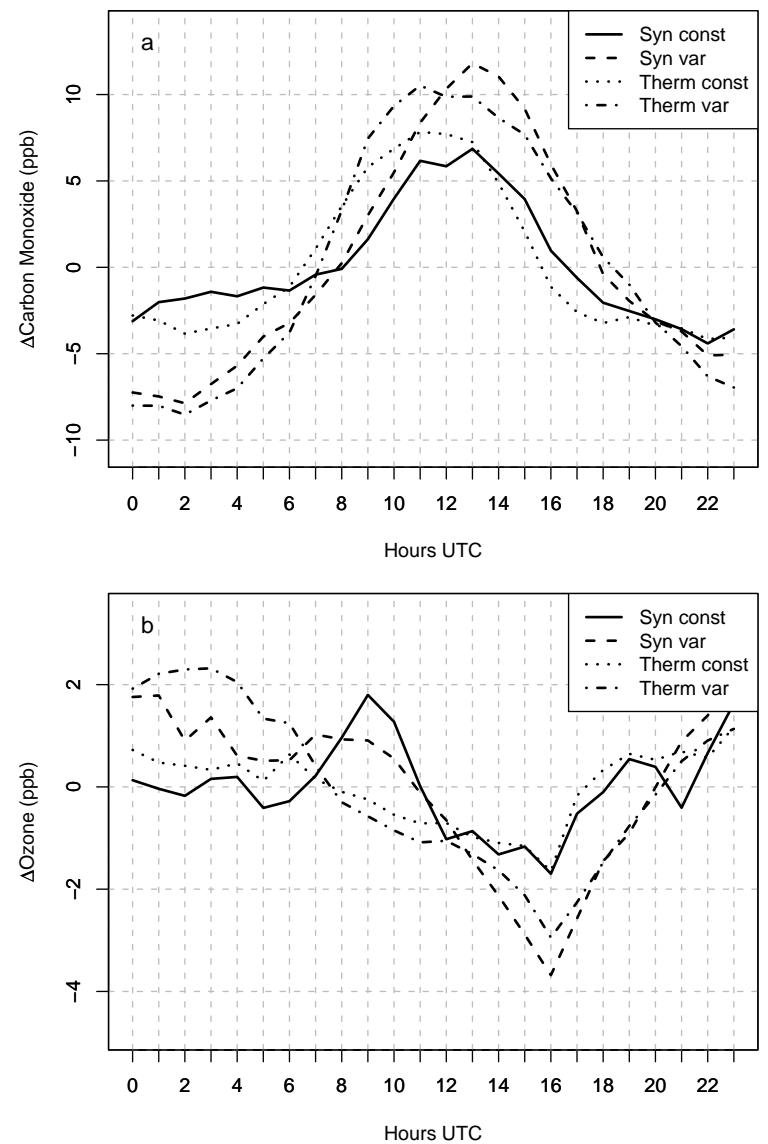

Fig. 2. Diurnal cycle of (a) carbon monoxide and (b) ozone anomalies for different categories (see text for details). There were 365 days $(67 \%)$ within the therm/var category, 93 days $(17 \%)$ in therm/const, 50 days (9\%) in syn/var, and 40 days (7\%) in syn/const. Note that the daily mean was subtracted before aggregation.

criterion categorised 415 days as days with variable specific humidity (var) and 133 as days with "constant" specific humidity (const).

$\mathrm{CO}$ measurements at MKN showed different diurnal behavior for the different categories (Fig. 2). For all categories a pronounced diurnal cycle was observed, indicating that also at days when no direct up-slope flow developed, the measurements were influenced by ABL air. The largest diurnal amplitudes were observed for days that also showed variable specific humidity (syn-var and therm-var), with an average $\mathrm{CO}$ amplitude of about $20 \mathrm{ppb}$. The maximum $\mathrm{CO}$ occurred two hours earlier for the therm-var category compared to the syn-var category. Using the same categorization of specific humidity Henne et al. (2008) observed similar results and concluded that next to direct vertical transport in the slope wind layer, the top of the convective boundary layer over the forelands can reach up to station altitude. On days showing thermally-induced circulations, both processes act
Table 1. Annual cycle of $\mathrm{O}_{3}$ mixing ratios (ppb) for different air mass origins. Values given in parentheses are expanded uncertainties $(p<0.05)$ of the mean.

\begin{tabular}{crrrrrr}
\hline Month & \multicolumn{6}{c}{ Cluster } \\
& EA & AP & AA & SIO & NA & NIO \\
\hline Jan & $26(1)$ & $32(1)$ & $35(1)$ & $25(2)$ & $-(-)$ & $30(1)$ \\
Feb & $21(2)$ & $34(1)$ & $41(2)$ & $-(-)$ & $-(-)$ & $30(1)$ \\
Mar & $30(1)$ & $34(1)$ & $31(1)$ & $30(3)$ & $33(5)$ & $32(1)$ \\
Apr & $31(1)$ & $33(3)$ & $37(6)$ & $28(1)$ & $26(1)$ & $31(1)$ \\
May & $34(1)$ & $39(1)$ & $41(1)$ & $26(1)$ & $31(1)$ & $-(-)$ \\
Jun & $39(1)$ & $38(1)$ & $42(2)$ & $33(1)$ & $34(1)$ & $39(2)$ \\
Jul & $35(1)$ & $36(1)$ & $43(6)$ & $33(1)$ & $35(1)$ & $-(-)$ \\
Aug & $32(1)$ & $35(2)$ & $-(-)$ & $32(1)$ & $33(1)$ & $30(1)$ \\
Sep & $35(1)$ & $37(1)$ & $-(-)$ & $34(1)$ & $36(1)$ & $34(2)$ \\
Oct & $27(1)$ & $20(2)$ & $-(-)$ & $28(1)$ & $32(1)$ & $24(3)$ \\
Nov & $24(1)$ & $24(1)$ & $25(3)$ & $24(1)$ & $24(3)$ & $21(1)$ \\
Dec & $27(2)$ & $29(1)$ & $36(4)$ & $20(2)$ & $-(-)$ & $22(1)$ \\
\hline
\end{tabular}

together and result in a rather broad day-time maximum of $\mathrm{CO}$, while on days when only convective mixing determines the increase in $\mathrm{CO}$, the maximum is shifted by two hours and showed a slower increase in the morning hours. On days that did not show a significant increase in specific humidity (const), the $\mathrm{CO}$ cycle was less pronounced and larger night time concentrations of $\mathrm{CO}(+5 \mathrm{ppb})$ were observed, possibly indicating the presence of residual layers in the FT. These conditions occurred during less than $25 \%$ of all nights. These data were retained for the climatological analysis. Again, an offset of $2 \mathrm{~h}$ for the diurnal maximum was visible between the therm and the syn categories.

The $\mathrm{O}_{3}$ diurnal cycle was amplified during days that showed significant increase in specific humidity (var), when lower afternoon and higher night-time values were observed. Conversely, during days that did not show a significant increase in specific humidity, the afternoon $\mathrm{O}_{3}$ minima were less pronounced. The diurnal cycle of ozone concentrations for the different categories compares well with the findings of the $\mathrm{CO}$ diurnal cycle in that days with stronger $\mathrm{ABL}$ influence experience lower $\mathrm{O}_{3}$ and higher $\mathrm{CO}$ afternoon concentrations.

In summary, throughout the whole year measurements at MKN were representative of free tropospheric conditions during night-time (21:00-04:00 UTC) only, while during day-time a mixture of boundary layer and free tropospheric air was usually sampled. The end of the period of FT conditions is well defined by the fact that at this time the down-slope flow (not shown) weakens and, shortly thereafter, concentrations of water vapor and $\mathrm{CO}$ start to rise. The start of the FT conditions is less well defined but the down-slope flow is most stable during the period 21:0004:00 UTC. In addition, variations in average $\mathrm{CO}$ and $\mathrm{O}_{3}$ within this period are small ( $3 \mathrm{ppb}$ and $1 \mathrm{ppb}$ ) compared to 

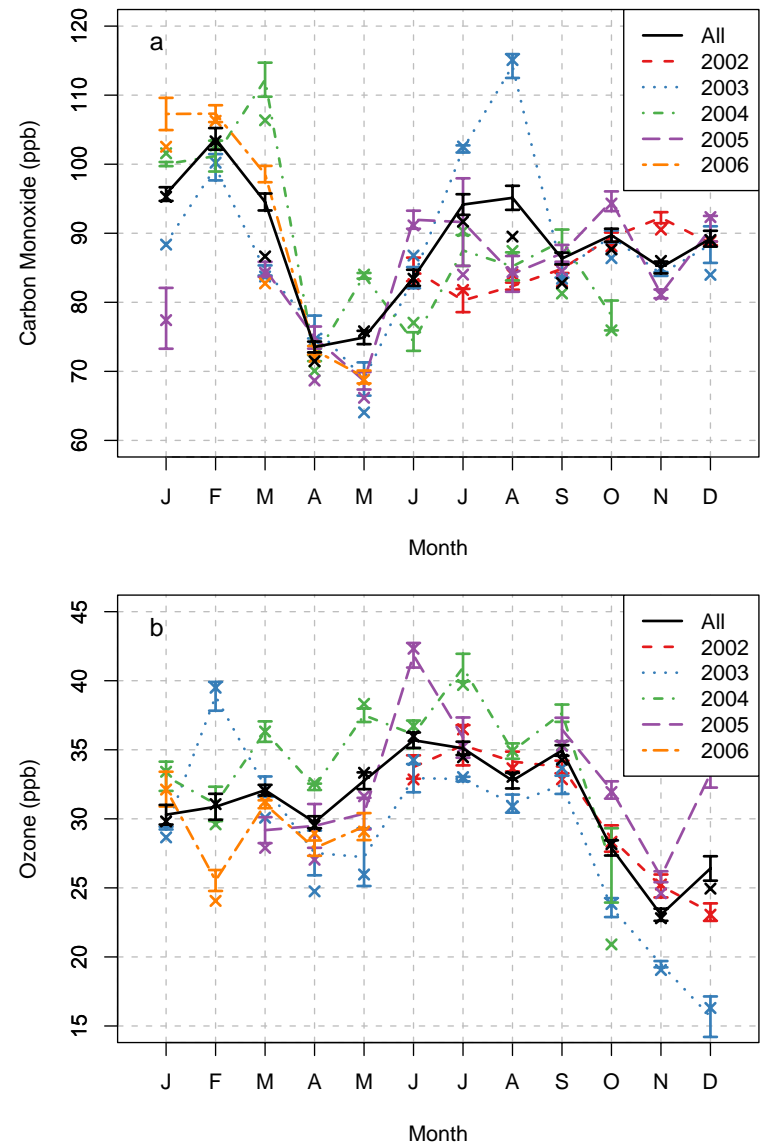

Fig. 3. Annual cycle of (a) carbon monoxide and (b) ozone. The black line represents the overall mean, while coloured lines refer to individual years. The error bars give the expanded uncertainty $(95 \%$ confidence level) of the monthly mean, including uncertainty due to incomplete data coverage.

the full diurnal amplitude of about $16 \mathrm{ppb}$ and $4 \mathrm{ppb}$, respectively. For species with distinctly larger (lower) concentrations in the ABL compared to the FT a stricter criterion for the selection of FT conditions (e.g. 01:00-04:00 UTC) might be necessary. Residual layers of increased $\mathrm{CO}$ and water vapour in the FT were present during nights categorised as "const".

\subsection{Annual cycle and large scale advection}

All further climatological analysis of the MKN measurements was therefore restricted to the free tropospheric observations (21:00-04:00 UTC). The overall average free tropospheric hourly CO mixing ratio at MKN was $94 \pm 16 \mathrm{ppb}$ ( $\hat{\mu} \pm 2 U, k=2$, night-time data only). $\mathrm{CO}$ experienced a pronounced annual cycle (Fig. 3a and Table 1). The largest mixing ratios were recorded for the months January to March, followed by a sharp decrease towards April and May and a recovery by the end of the year. In 2003 a strong increase in
Table 2. Annual cycle of night-time (21:00-04:00 UTC) CO and $\mathrm{O}_{3}$ mixing ratios (ppb) measured at MKN in the period 1 June 2002 to 1 June 2006. $\bar{x}$ : Mean, $u_{x}$ : expanded uncertainty $(p<0.05)$ of the mean, $\alpha_{10}: 10 \%$ percentile, $\alpha_{90}: 90 \%$ percentile.

\begin{tabular}{lrccrcccc}
\hline Month & \multicolumn{4}{c}{$\mathrm{CO}$} & \multicolumn{4}{c}{$\mathrm{O}_{3}$} \\
& $\bar{x}$ & $u_{x}$ & $\alpha_{10}$ & $\alpha_{90}$ & $\bar{x}$ & $u_{x}$ & $\alpha_{10}$ & $\alpha_{90}$ \\
\hline Jan & 96 & 1.0 & 78 & 113 & 30 & 0.7 & 20 & 42 \\
Feb & 104 & 1.6 & 85 & 121 & 31 & 0.9 & 15 & 45 \\
March & 95 & 1.2 & 74 & 135 & 32 & 0.4 & 22 & 42 \\
April & 74 & 0.8 & 61 & 91 & 30 & 0.4 & 20 & 39 \\
May & 75 & 1.0 & 60 & 88 & 33 & 0.6 & 22 & 44 \\
June & 84 & 1.2 & 68 & 99 & 36 & 0.6 & 26 & 45 \\
July & 94 & 1.5 & 75 & 111 & 35 & 0.5 & 27 & 44 \\
Aug & 95 & 1.7 & 75 & 128 & 33 & 0.6 & 25 & 40 \\
Sep & 86 & 0.8 & 70 & 107 & 35 & 0.4 & 24 & 46 \\
Oct & 90 & 0.9 & 72 & 111 & 28 & 0.6 & 15 & 40 \\
Nov & 85 & 0.9 & 71 & 96 & 23 & 0.4 & 14 & 31 \\
Dec & 89 & 1.1 & 77 & 104 & 26 & 0.9 & 16 & 39 \\
\hline
\end{tabular}

CO mixing ratios in the months of July and August led to a secondary maximum in the annual cycle and also induced a secondary maximum in the overall annual cycle. All other years showed average $\mathrm{CO}$ concentrations during this time of the year. The overall average free tropospheric hourly $\mathrm{O}_{3}$ mixing ratio at $\mathrm{MKN}$ was $29 \pm 3 \mathrm{ppb}(\hat{\mu} \pm 2 U, k=2$, nighttime data only). In contrast to $\mathrm{CO}, \mathrm{O}_{3}$ mixing ratios showed little deviation from the overall mean from January to May (Fig. 3b and Table 2). For the months of June to September, $\mathrm{O}_{3}$ as well as $\mathrm{CO}$ mixing ratios were enhanced, while for the months of October to December, $\mathrm{O}_{3}$ mixing ratios were reduced by about $5 \mathrm{ppb}$.

The general annual cycle of $\mathrm{CO}$ and $\mathrm{O}_{3}$ at $\mathrm{MKN}$ can be explained by the seasonal variation of monsoon flow over equatorial East Africa (Fig. 4), which is determined by the seasonal displacement of the inter-tropical convergence zone (ITCZ) (Asnani, 1993; Leroux, 2001; Slingo et al., 2005). Throughout boreal winter, the ITCZ is situated south of the equator $\left(10-15^{\circ} \mathrm{S}\right)$ extending from the northern tip of Madagascar towards southern Tanzania and then northward towards Lake Victoria. Consequently, East Africa is generally dominated by north-easterly monsoon, carrying northernhemispheric air towards Kenya that is enriched in CO during the winter season (Novelli et al., 1998a, 2003) but depleted in $\mathrm{O}_{3}$, resulting in high $\mathrm{CO}$ and moderate $\mathrm{O}_{3}$ concentrations at MKN. When the ITCZ starts to progress northward again, it brings a period of "long rains" from mid-March to the beginning of June to equatorial East Africa and with it clean air from the Indian ocean, causing the distinct spring-time minimum in $\mathrm{CO}$. Although low $\mathrm{O}_{3}$ concentrations would be expected under the influence of clean maritime air, $\mathrm{O}_{3} \mathrm{lev}$ els remained moderate at MKN. A more detailed study of the transport pathways towards MKN is given in Sect. 3.4 to 


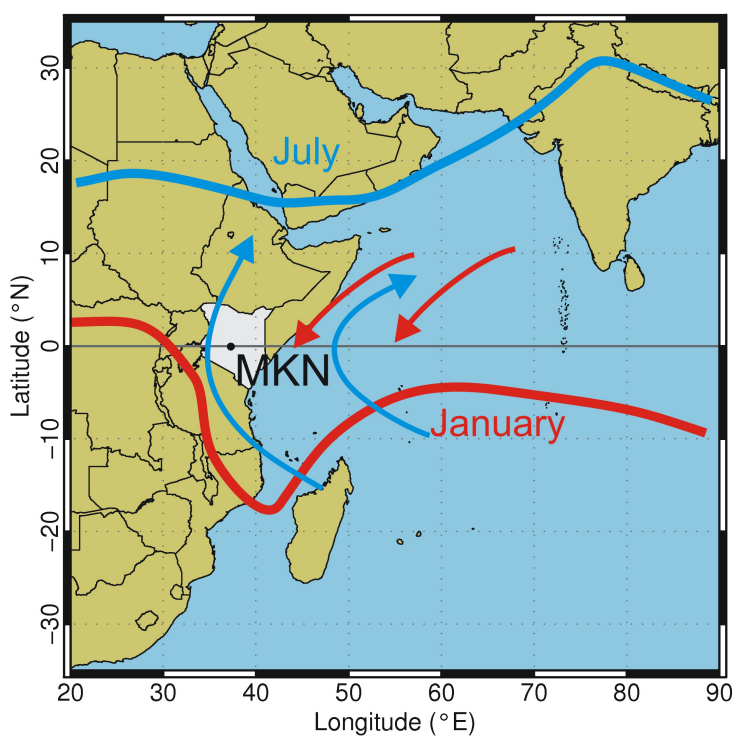

Fig. 4. Schematic position of the ITCZ (bold lines) and associated flow (arrows) over the western Indian Ocean for the month July and January. The position of the Mt. Kenya site is marked with a black dot.

elucidate this discrepancy. During boreal summer, the ITCZ is situated far to the North over India $\left(15-20^{\circ} \mathrm{N}\right)$ and along the southern coast of the Arabian Peninsula $\left(10-15^{\circ} \mathrm{N}\right)$, resulting in southerly to south-easterly winds over Kenya. CO mixing ratios in the southern hemisphere increase during boreal summer due to enhanced biomass burning emissions (Novelli et al., 1998a, 2003) and peak in boreal fall (Bremer et al., 2004; Edwards et al., 2006a). Consequently, increased $\mathrm{CO}$ and $\mathrm{O}_{3}$ concentrations are transported towards equatorial Africa from June to October. When the ITCZ crosses over Kenya from mid-October to December it brings a second rainy period with strongly reduced $\mathrm{O}_{3}$ but only slightly reduced $\mathrm{CO}$ concentrations. This might indicate flow from the northern hemispheric marine boundary layer where $\mathrm{O}_{3}$ is photochemically destroyed at rates of $2-6 \mathrm{ppb} \mathrm{d}^{-1}$, while $\mathrm{CO}$ concentrations increase due to pollution outflow from India (Lelieveld et al., 2001). From a meridional cross section of $\mathrm{O}_{3}$ soundings in the Indian Ocean in February/March 1999, Saraf et al. (2003) report the lowest $\mathrm{O}_{3}$ mixing ratios within the maritime boundary layer in the ITCZ. Mixing ratios ranged from below $30 \mathrm{ppb}$ to $650 \mathrm{hPa}$, which is in line with the $\mathrm{MKN} \mathrm{O}_{3}$ measurements during ITCZ passage around November.

\subsection{Regions of influence}

Depending on the flow regime, an individual site might be representative of various, discrete areas. Six different regions of influence were determined for MKN by trajectory clustering. These air masses are presented in Fig. 5 in the form of residence time plots for individual trajectory clusters. In addition, monthly residence time maps (not shown) were compared to identify seasonal variability in the flow within each cluster. The observed clusters can be described as follows:

East Africa (EA, Fig. 5a): this cluster describes situations with relatively low wind speeds, air originating relatively close to the surface and possible recirculation over eastern Africa. It represents $21 \%$ of the airflow towards MKN. Advection was mostly from the East with little contribution from the West, though with generally lower wind speeds. During the rainy seasons (Apr, Nov; not shown) the air mass origin was more local and easterly, indicating the presence of the ITCZ over Kenya.

Arabian Peninsula (AP, Fig. 5b): during $16 \%$ of the time advection towards MKN was from the Arabian Peninsula and Pakistan across the Horn of Africa. The transport was in general directed downward within the Arabian high pressure system. From May to September the air mass origin was more continental from central Arabia (not shown), while from October to March the origin was shifted towards the eastern coast of the Arabian Peninsula.

Northern Africa (NA, Fig. 5c): air masses combined in this cluster contributed $6 \%$ and were transported downward from the upper troposphere with little contact with the surface and originated over western North Africa. Part of the flow occurred close to or within the subtropical jet as indicated by large wind speeds. In February the upper level flow extended further east over the northern Indian Ocean than during the other months (not shown).

Southern Indian Ocean (SIO, Fig. 5d): advection was mainly over the south-western Indian Ocean with most air masses arriving over Africa at the coastline between Kenya and Tanzania. The northern end of Madagascar was often within the catchment area of this air stream. The flow was close to the surface, generally ascending towards the East African highlands and can be associated with flow within the active phase of the East African Low Level jet (Findlater, 1969). It contributed $21 \%$ to the total flow towards MKN. No seasonal variation within this transport pattern was observed.

Southern Africa (SA, Fig. 5e): in contrast to the SIO cluster, air flow was more from the south along the coastal areas of Tanzania and northern Mozambique and often originating over Madagascar. In total SA contributed $18 \%$ to air flow towards MKN. Air masses stayed close to the ground during most of the transport and were in contact with the surface over Malawi and eastern South Africa. No seasonal variation within this transport pattern was observed.

Northern Indian Ocean (NIO, Fig. 5f): during 17\% of the time advection was from India over the northern Indian Ocean. Often the air masses stayed at altitudes higher than $2000 \mathrm{~m}$ a.g.l. and therefore above the trade wind inversion. From May to October the air mass origin was shifted to higher altitudes (not shown). 

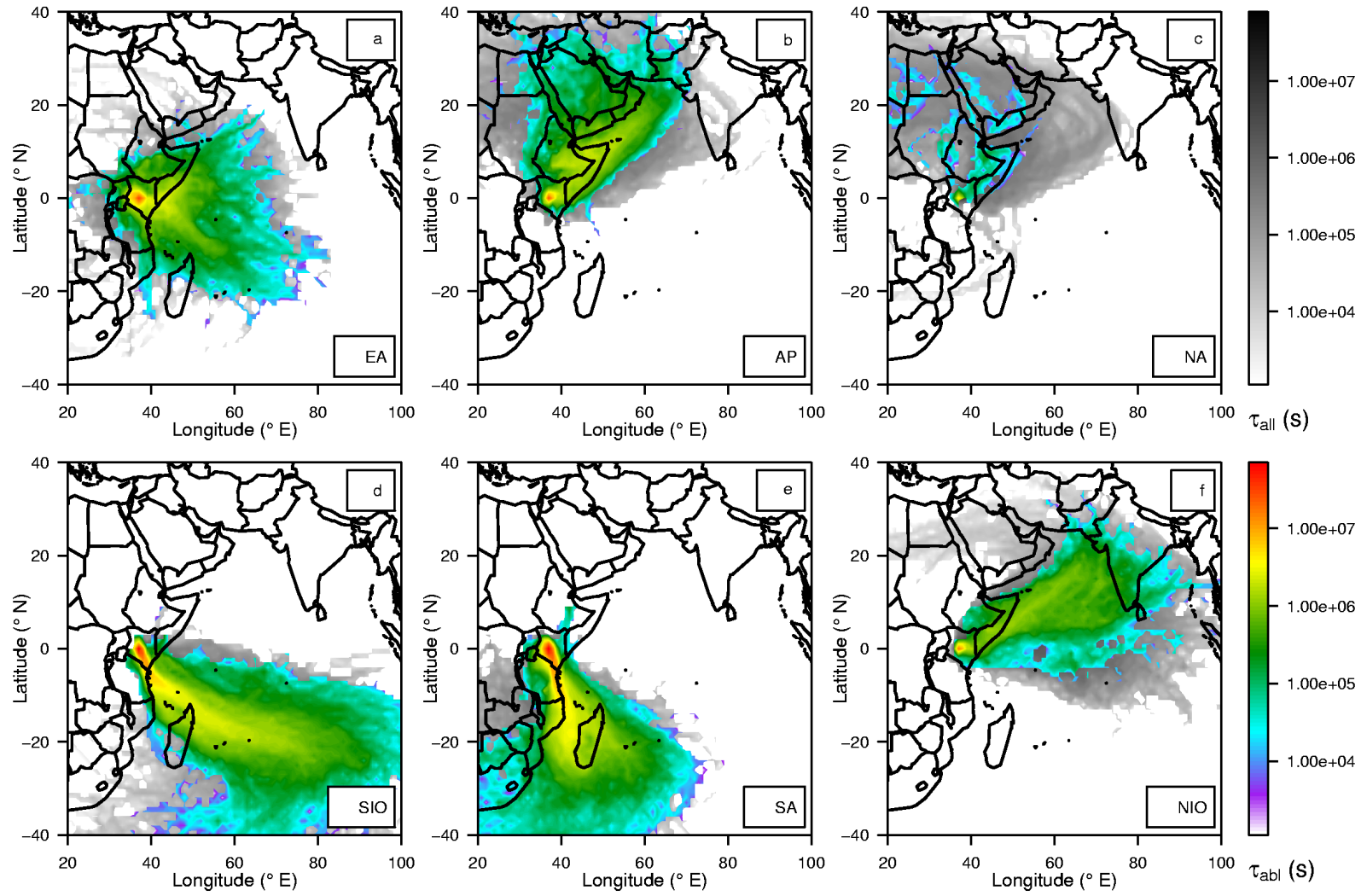

Fig. 5. Trajectory residence time plots for different trajectory clusters: (a, EA) East Africa, (b, AP) Arabian Peninsula, (c, NA) North Africa, (d, SIO) Southern Indian Ocean, (e, SA) Southern Africa, (f, NIO) Northern Indian Ocean. Residence times are estimated by evaluating how much time an air parcel traveling along an individual trajectory spent in a certain grid cell and altitude range. The total residence times for a category are derived by summation over all trajectories in the category. Residence times are given in seconds. The grey shades refer to residence times in the total tropospheric column, while the rainbow colours refer to residence times below $2000 \mathrm{~m}$ above model ground.

The distinct seasonal pattern of the monsoon flow over the Indian Ocean can be seen in the varying occurrence of the individual clusters during the year (Fig. 6 and supplementary material). The situations with northern hemispheric advection dominated from November to March, while the southern hemispheric situations dominated from May to October. The EA cluster could be observed all year round with largest contributions during the rainy seasons, i.e. April and October. The descending flow pattern NA was most prominent from January to May. Although the contribution of the AP cluster was smaller during summer, it did not cease completely, in contrast to the contribution of the NIO and NA clusters. In general, the air mass categorization using trajectory clustering yielded similar results to those reported before for the airflow towards Kenya by Gatebe et al. (1999). They manually categorized backward trajectories for the years 1991 to 1993 , resulting in 6 categories that were slightly different from the ones described in this study. Instead of two categories of advection from the northern and southern Indian Ocean respectively (AP, NIO and SA, SIO in our study) they defined one category per hemisphere. In contrast, they de- scribed a category of very rare westerly air flow arriving from the Atlantic Ocean after crossing equatorial Africa that was not observed during our study period. Furthermore, they observed two types of recirculation patterns within Kenya and eastern Africa that compare to our EA category. Apart from this, our findings for the annual cycle of different air mass contributions agree well with their study.

Due to variations in $\mathrm{CO}$ background mixing ratios and emission source strengths from biomass burning, CO mixing ratios within the different clusters also showed a strong annual cycle (Fig. 7a and Table 3). The cycle for the EA category was similar to the overall annual cycle, showing a semi-annual pattern with a pronounced minimum during April/May and a less pronounced minimum in November. The boreal spring maximum seen for the AP category was more pronounced than average, while concentrations stayed low during boreal summer. The AP category therefore was clearly dominated by the northern hemispheric $\mathrm{CO}$ annual cycle. Although originating from higher altitudes, air masses within the NA category also experienced a boreal springtime maximum and lower concentrations throughout the rest 


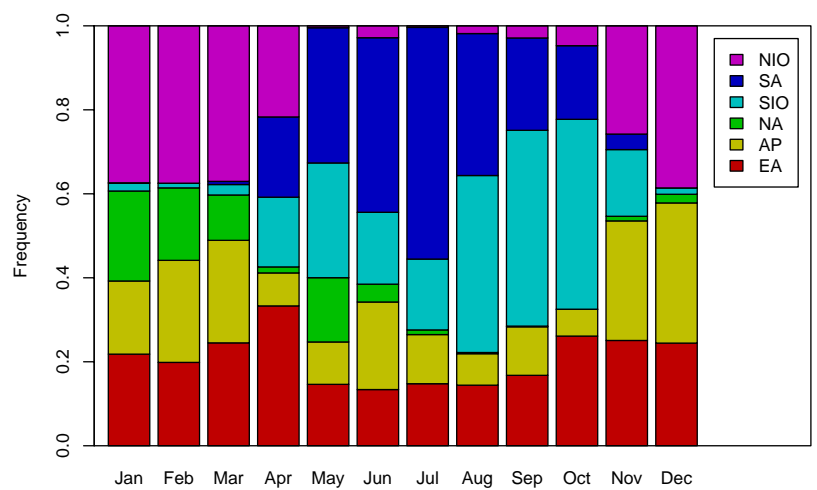

Fig. 6. Annual cycle of the relative frequency for different trajectory clusters.
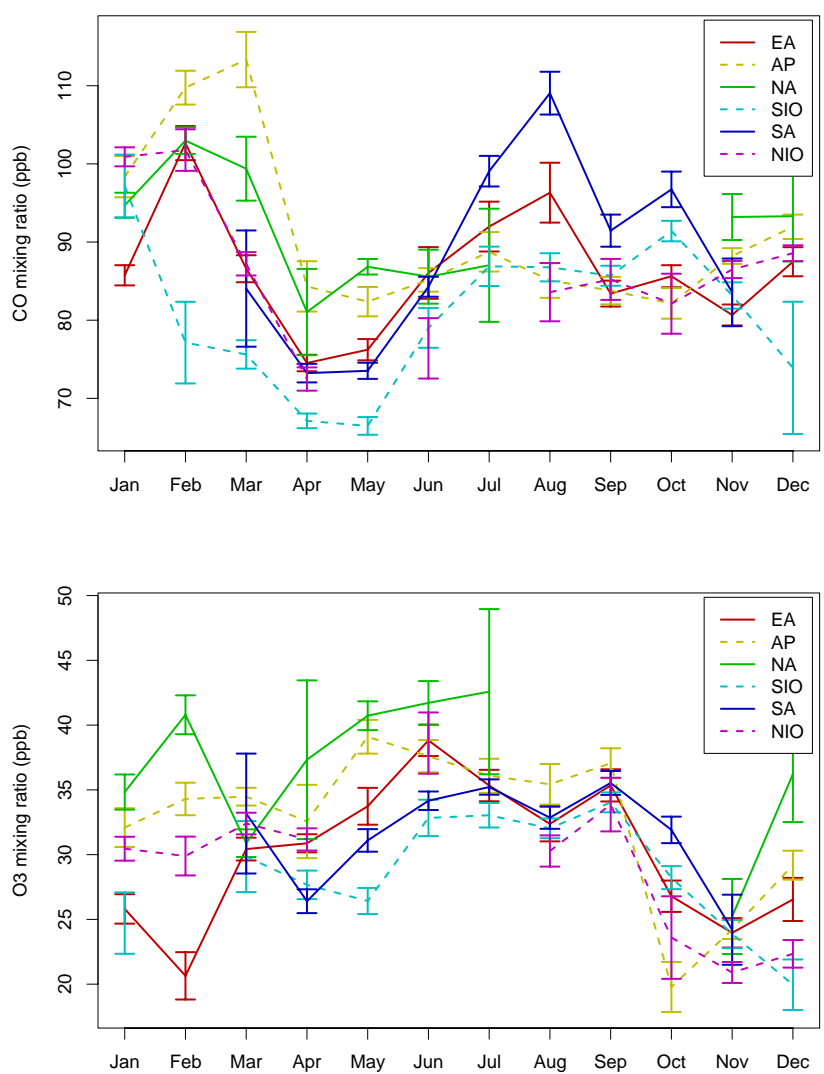

Fig. 7. Annual cycle of (a) carbon monoxide and (b) ozone for different trajectory clusters. The error bars give the expanded $(\mathrm{k}=2)$ uncertainty of the monthly cluster means.

of the year, representing northern hemispheric, free tropospheric conditions. A similar annual cycle was observed for NIO conditions, however, with generally lower CO concentrations when compared to NA conditions. This is surprising since large $\mathrm{CO}$ concentrations were expected from the winter-time outflow of emissions from India. This outflow, however, is confined below $4 \mathrm{~km}$ and to the marine boundary layer; its vertical extent is limited by the trade wind inversion (de Laat et al., 2001). CO mixing ratios from January to March within the NIO category were around $100 \mathrm{ppb}$, similar to those reported by de Gouw et al. (2001) for the altitude range 3-8 km (100-130 ppb), but considerably lower than the previously reported $140 \mathrm{ppb}$ for the marine boundary layer over the northern Indian Ocean during this season (Stehr et al., 2002). The $\mathrm{MKN} \mathrm{O}_{3}$ mixing ratios during the same period were on the order of $30 \mathrm{ppb}$ and comparable to measurements in the maritime boundary layer that were under northern hemisphere, continental influence (Stehr et al., 2002), but higher than the average maritime $\mathrm{O}_{3}(\sim 20 \mathrm{ppb})$ for the 3-8 km altitude range (de Gouw et al., 2001).

In contrast to the northern hemispheric categories, the southern hemispheric categories showed an annual cycle with pronounced maxima during austral winter and lower concentrations during austral summer. Thus, the SA category exhibited a larger maximum driven by biomass burning emissions from continental Africa, while the SIO category was representative for the southern Indian Ocean background with the lowest $\mathrm{CO}$ of all between February and June.

Ozone revealed less between-category variation than $\mathrm{CO}$ (Fig. 7b and Table 3). Most categories showed a minimum from October to December. There was a tendency to larger $\mathrm{O}_{3}$ concentrations for the NA category, most likely due to the origin at higher altitudes. In contrast, $\mathrm{O}_{3}$ was lowest in the SIO category due to the origin in the marine boundary layer of the remote Indian Ocean. Both SA and SIO showed an $\mathrm{O}_{3}$ maximum during austral winter, the southern hemispheric biomass burning season. The maximum was more pronounced for the continental origin (SA) than for the maritime origin (SIO). However, the maximum was less distinct than that observed by MOZAIC flights within the lower FT $\left(\mathrm{O}_{3}=80-100 \mathrm{ppb}\right)$ over western equatorial sites in Africa, but agreed with the observation of only small $\mathrm{O}_{3}$ enhancements during boreal summer over Nairobi (Sauvage et al., 2005). During SAFARI 2000 even larger $\mathrm{O}_{3}$ (>120 ppb) concentrations were observed over Zambia in a layer reaching from 800 to $500 \mathrm{hPa}$ as a result of pollutant recirculation within the south African haze layer (Thompson et al., 2002).

\subsection{Influence of southern African biomass burning on inter- annual variability}

Inter-annual variability in the $\mathrm{CO}$ and $\mathrm{O}_{3}$ observations at MKN can be caused by both variability in the transport patterns and variability in $\mathrm{CO}$ emission strengths, mainly from biomass burning. Inter-annual variability was largest during the southern hemispheric biomass burning season (Fig. 3). During this period stable high pressure conditions exist over large parts of southern Africa, hindering vertical transport and favoring accumulation and recirculation of biomass burning emissions over the area ("south African haze layer", Garstang et al., 1996). According to Swap et al. (2003) and Edwards et al. (2006a) pollutants within this haze 
Table 3. Annual cycle of night-time $\mathrm{CO}$ and $\mathrm{O}_{3}$ mixing ratios (ppb) for different air mass origins. Values given in parentheses are expanded uncertainties $(p<0.05)$ of the mean.

\begin{tabular}{|c|c|c|c|c|c|c|c|c|c|c|c|c|}
\hline Month & EA & $\mathrm{AP}$ & $\stackrel{\mathrm{AA}}{\mathrm{C}}$ & SIO & NA & NIO & EA & AP & $\mathrm{AA}$ & SIO & NA & $\mathrm{NIO}$ \\
\hline Jan & $86(1)$ & $98(3)$ & $95(2)$ & 97 (4) & $-(-)$ & $101(1)$ & $26(1)$ & $32(1)$ & $35(1)$ & $25(2)$ & $-(-)$ & $30(1)$ \\
\hline Feb & $103(2)$ & $110(2)$ & $103(2)$ & 77 (5) & $-(-)$ & $102(3)$ & $21(2)$ & 34 (1) & $41(2)$ & $-(-)$ & $-(-)$ & $30(1)$ \\
\hline March & 87 (2) & $113(4)$ & 99 (4) & $76(2)$ & $84(7)$ & 87 (1) & $30(1)$ & 34 (1) & $31(1)$ & $30(3)$ & $33(5)$ & $32(1)$ \\
\hline April & $75(1)$ & $84(3)$ & $81(6)$ & $67(1)$ & $73(1)$ & $72(1)$ & $31(1)$ & $33(3)$ & $37(6)$ & $28(1)$ & $26(1)$ & $31(1)$ \\
\hline May & $76(1)$ & $82(2)$ & 87 (1) & $66(1)$ & 74 (1) & $-(-)$ & $34(1)$ & 39 (1) & $41(1)$ & $26(1)$ & $31(1)$ & $-(-)$ \\
\hline June & $86(3)$ & 85 (2) & $86(3)$ & $79(3)$ & 84 (1) & $76(4)$ & 39 (1) & $38(1)$ & $42(2)$ & $33(1)$ & $34(1)$ & 39 (2) \\
\hline July & $92(3)$ & 89 (3) & 87 (7) & 87 (3) & 99 (2) & $-(-)$ & 35 (1) & $36(1)$ & $43(6)$ & $33(1)$ & $35(1)$ & $-(-)$ \\
\hline Aug & $96(4)$ & 85 (2) & $-(-)$ & 87 (2) & 109 (3) & 84 (4) & $32(1)$ & $35(2)$ & $-(-)$ & $32(1)$ & $33(1)$ & $30(1)$ \\
\hline Sep & $83(2)$ & 84 (2) & $-(-)$ & $86(1)$ & $91(2)$ & $85(3)$ & $35(1)$ & 37 (1) & $-(-)$ & $34(1)$ & $36(1)$ & $34(2)$ \\
\hline Oct & $86(1)$ & $82(2)$ & $-(-)$ & $91(1)$ & 97 (2) & $82(4)$ & $27(1)$ & $20(2)$ & $-(-)$ & $28(1)$ & $32(1)$ & $24(3)$ \\
\hline Nov & 81 (1) & 88 (1) & $93(3)$ & $83(2)$ & $84(4)$ & $86(1)$ & $24(1)$ & $24(1)$ & $25(3)$ & $24(1)$ & $24(3)$ & 21 (1) \\
\hline Dec & 87 (2) & $92(2)$ & $93(6)$ & $74(8)$ & $-(-)$ & 89 (1) & $27(2)$ & $29(1)$ & $36(4)$ & $20(2)$ & $-(-)$ & $22(1)$ \\
\hline
\end{tabular}

layer reach maximal concentrations from August to October, while the maximum at MKN is reached in July/August. Pollutants emitted in south-eastern Africa can readily be exported towards the Indian Ocean and then northward towards Kenya as presented in the SA transport pattern. This transport category was maximal in July and ceased afterwards, while the maritime SIO pattern dominated from August to October (Fig. 6). Therefore, the peak CO concentrations observed at MKN in July/August can be explained as a combination of increased occurrence of the SA transport pathway and moderately increased $\mathrm{CO}$ concentrations over southern Africa, while during September/October, when concentrations maximize in southern Africa, transport towards Kenya tends to be more directly from the Indian Ocean (SIO cluster).

To estimate the influence of biomass burning on interannual variability, we analyzed fire counts and fire radiative power (FRP) as retrieved by Moderate Resolution Imaging Spectroradiometer (MODIS) sensors on board NASA satellites Terra and Aqua (Justice et al., 2002; Giglio et al., 2006) on a regional basis for the years 2002-2006. We used the climate modeling grid product (cloud-and-overpass corrected) with a horizonal resolution of $0.5^{\circ} \times 0.5^{\circ}$ and monthly temporal resolution as described by Giglio et al. (2006). Southern African countries were grouped as follows: (Central) Zambia, Angola, Dem. Rep. Congo; these regions were not directly covered by any of the MKN footprints, but large-scale emissions might still increase the continental-scale background and therefore influence MKN during SA conditions. (Eastern) Mozambique, Zimbabwe, Malawi, Madagascar; (Southern) Botswana, South Africa, Swaziland, Namibia. The eastern and southern regions lie well within the footprint of the SA pattern and therefore directly influence measurements at MKN, while the SIO regime only touched the very eastern parts of these regions. Kenya and Tanzania were treated separately to estimate the local to regional influence of biomass burning on MKN.
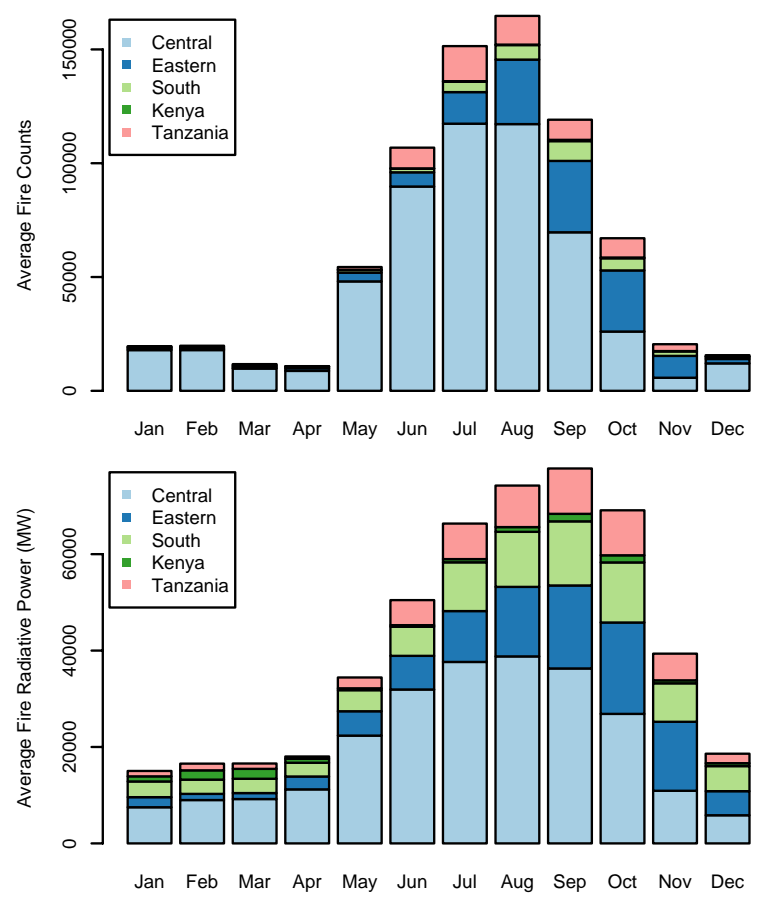

Fig. 8. Average annual cycle of fire counts (top) and fire radiative power (bottom) for different regions in southern and central Africa. Central: Zambia, Angola, Dem. Rep. Congo; eastern: Mozambique, Zimbabwe, Malawi, Madagascar; South: Botswana, South Africa, Swaziland, Namibia.

The overall fire count maximum in southern Africa was reached in August (Fig. 8a), while for the central region, the largest contributor to total fire counts, the maximum was reached earlier in July/August, slightly later than observed during the La Niña year 2000 (Silva et al., 2003). In the eastern and southern regions fire counts peaked in September. Their overall contribution to total fire counts was small, while the contribution of Tanzania and especially Kenya 
Table 4. Characteristics of detected biomass burning plumes. Values given in parenthesis are expanded uncertainties $(p<0.05)$. $\mathrm{CO}$ and $\mathrm{O}_{3}$ mixing ratios are mean values. Total FRP is given in arbitrary units resulting from scaling in the transport simulation.

\begin{tabular}{llcccccccc}
\hline Start & End & No. & $R^{2}$ & $\begin{array}{c}\text { Slope } \\
(\mathrm{ppb} / \mathrm{ppb})\end{array}$ & $\begin{array}{c}\text { Age } \\
(\mathrm{d})\end{array}$ & $\begin{array}{c}\mathrm{CO} \\
(\mathrm{ppb})\end{array}$ & $\begin{array}{c}\mathrm{O}_{3} \\
(\mathrm{ppb})\end{array}$ & Total FRP & Origin \\
\hline 3 February 2004 & 6 February 2004 & 25 & 0.83 & $0.23(0.02)$ & $3.7(0.5)$ & 178 & 44 & 0.50 & Sudan, Ethiopia \\
6 March 2004 & 10 March 2005 & 28 & 0.22 & $0.67(0.23)$ & $4.2(0.8)$ & 140 & 38 & 0.05 & Sudan, Ethiopia \\
26 September 2004 & 30 September 2004 & 30 & 0.61 & $0.62(0.12)$ & $4.3(0.9)$ & 128 & 43 & 0.25 & Mozambique, Madagascar \\
1 March 2006 & 5 March 2006 & 33 & 0.65 & $0.35(0.04)$ & $4.3(0.6)$ & 140 & 31 & 0.14 & Sudan, Ethiopia \\
\hline
\end{tabular}

itself was negligible. Pollutant emissions are not directly proportional to fire counts but depend on the amount and type of vegetation burned, and the burning conditions. FRP offers a quantity that, when integrated over time, is more proportional to the amount of biomass burnt (Wooster et al., 2005; Roberts et al., 2005). With respect to the seasonal cycle of the MODIS FRP in southern Africa (Fig. 8b), the month of peak FRP (September) was delayed by one month compared to the fire count seasonal cycle, which is in better agreement with the observed maximum pollutant concentrations in southern Africa. The contribution of the central region to total FRP was less dominant as for fire counts, while the contribution of Tanzania and Kenya remained small. In contrast to the sharp decrease in fire counts in October, FRP remained high especially in the eastern region, sustaining high pollutant levels. An additional factor increasing emissions at the end of the biomass burning season that is not easily identified by satellite retrieved fire counts or FRP might be the transition from the burning of less dense vegetation in the western part of southern Africa earlier during the year to denser vegetation in the eastern part from August to October. This phenomenon might be coupled to a transition from more efficient burning conditions to less efficient conditions, when dense vegetation tends to burn in smoldering fires.

Inter-annual variability in regional fire radiative power (Fig. 9) and in the two dominating transport patterns in boreal summer (SA and SIO, Fig. 10) were used to explain variations in the MKN observations. The most prominent anomaly in monthly $\mathrm{CO}$ concentrations was observed in July/August 2003, when concentrations reached an overall summer-time maximum. This increase was most likely caused by more frequent transport in category SA throughout the whole summer 2003, while, especially for August, the contribution of SIO was lower than in other years. No increase in biomass burning as determined from regional FRP sums was observed. Average biomass burning occurred in the eastern and central region. Local (Kenyan) biomass burning activity was above average from August to October of that year and might have contributed to CO levels in August. Although CO was strongly enhanced during August 2003, $\mathrm{O}_{3}$ was below average. The correlation between $\mathrm{O}_{3}$ and CO was relatively large $\left(r^{2}=0.3\right)$ compared to other months.
However, this value still indicates little photochemical origin of $\mathrm{O}_{3}$. One reason could be that the sources of $\mathrm{CO}$ were poor in $\mathrm{NO}_{\mathrm{x}}$ emission, which would be the case for smoldering fires. These are more likely to occur within the denser vegetation of the East African highlands, where more active fires were detected during August 2003, than in Savannah-type vegetation further to the south.

In June 2005 both $\mathrm{CO}$ and $\mathrm{O}_{3}$ concentrations were above average (Fig. 3). Although Edwards et al. (2006b) observed little inter-annual variation in fire counts for the whole south African subcontinent, we detected strong inter-annual variability on the regional scale. Biomass burning in the eastern region was intensified in 2005 throughout the early burning season, starting as early as March and remaining elevated until the end of July (Fig. 9). Since transport from SA in June 2005 was reduced (Fig. 10), the increased CO at MKN was most likely caused by increased emissions in the eastern biomass burning region. In general, $\mathrm{CO}$ concentrations were low in July/August 2002, caused by less frequent transport from southern Africa. Below average CO concentrations in May 2005 occurred together with increased transport of clean air from the southern Indian Ocean. Increased CO concentrations observed in November 2002 (when advection towards MKN was more directly from the east) were associated with increased biomass burning over Indonesia (Edwards et al., 2006b).

\section{6 $\mathrm{O}_{3}-\mathrm{CO}$ correlations}

For each year, monthly $\mathrm{O}_{3}-\mathrm{CO}$ correlation coefficients were calculated for the 1-hourly night-time measurements at MKN (including pollution event data that were previously omitted from the climatological study). Significant correlations $\left(R^{2}>0.2, p<0.01\right)$ were only observed for some individual months and not for all years. Only for May and October were $\mathrm{O}_{3}-\mathrm{CO}$ correlations significant for 3 out of 4 years with slopes of $0.8-1.6 \mathrm{ppb} / \mathrm{ppb}$ and $0.8-2 \mathrm{ppb} / \mathrm{ppb}$, respectively. These numbers indicate aged air masses, but the interpretation remains uncertain since the correlations were not highly significant. The Tropospheric Emission Spectrometer (TES) retrieves $\mathrm{O}_{3}$ and $\mathrm{CO}$ concentrations at $618 \mathrm{hPa}$. Global maps of $\mathrm{O}_{3}-\mathrm{CO}$ correlations were obtained for July 2005 (Zhang et al., 2006). In agreement with our results no significant 

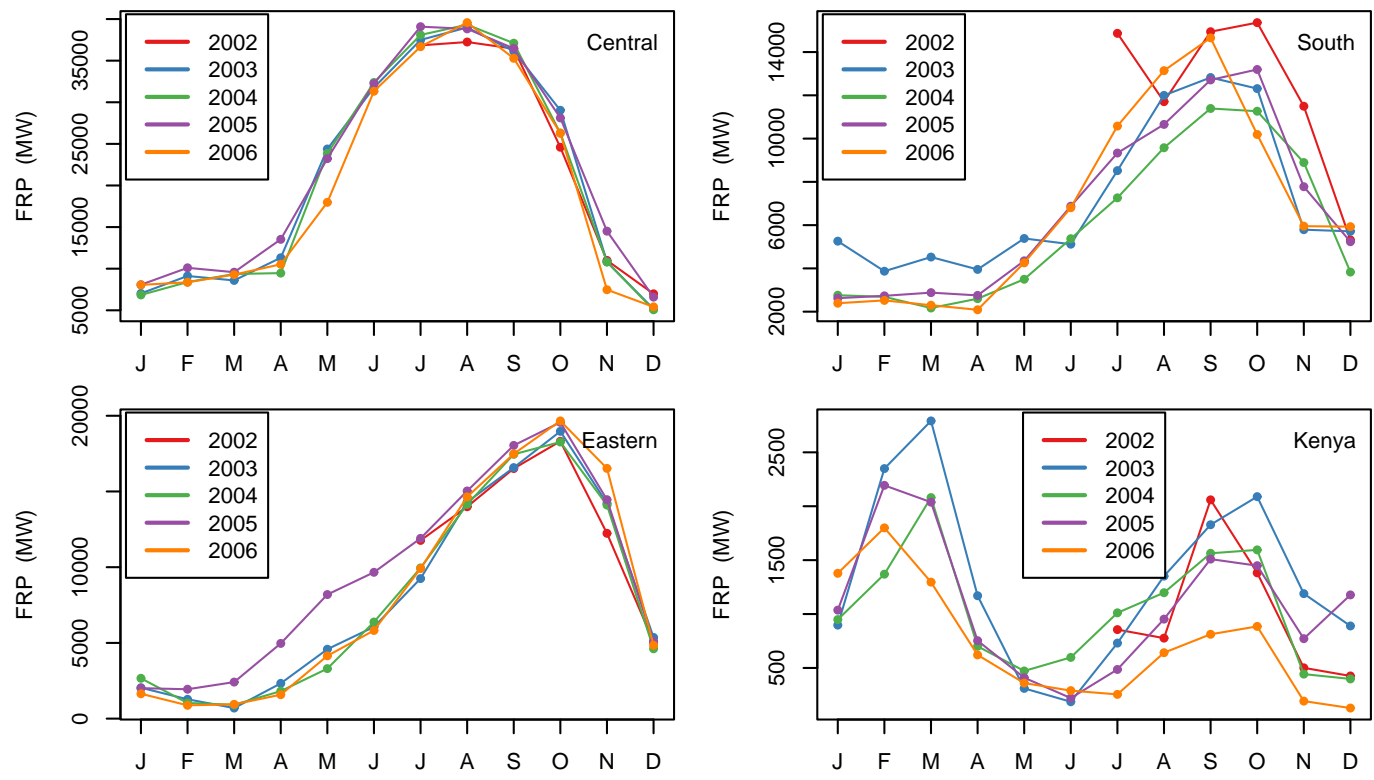

Fig. 9. Annual cycle of fire radiative power for different regions in southern and central Africa. See text for definition of regions. Note differenty-scales.

$(|R|<0.2)$ correlations were found over equatorial eastern Africa, while in central to southern Africa slopes were between 0.6 and 0.8 . These low correlations can be indicative of very aged air masses or of air masses with different background concentrations influencing the station within the same month (Parrish et al., 1998).

Separating the $\mathrm{O}_{3}$ and $\mathrm{CO}$ measurements by air mass origin, correlations were calculated for different influence regions. Overall only the SIO origin showed a significant correlation when taking all data into account, with a slope of 1.1 and $R^{2}=0.25$. On a monthly basis correlations for different air mass origins improved, with the largest correlations $\left(R^{2}=0.6-0.8\right)$ obtained for the SIO cluster from April to June and a slope of $0.5-1$. This might be indicative of photochemical destruction of both species over the remote Indian Ocean. The correlation was also slightly significant $\left(R^{2}=0.25\right)$ for the SA cluster in September with a slope of 0.4 that is more representative of recent biomass burning plumes.

Although MKN was rarely directly influenced by biomass burning events, these were evaluated in terms of their $\mathrm{O}_{3}$ $\mathrm{CO}$ relationship. To determine events with increased $\mathrm{CO}$ related to biomass burning, MODIS fire radiative power $\left(0.5^{\circ} \times 0.5^{\circ}\right.$ horizontal and 8 day temporal resolution) was evaluated along the back trajectories arriving at MKN. Fire radiative power along each back trajectory was summed for the reference and the uncertainty trajectories at times when the trajectory was less than $2000 \mathrm{~m}$ above model ground. A weighted average fire radiative power for each arrival time was then derived by giving a weight of 1 to the reference and $1 / 6$ to each of the 6 uncertainty trajectories. Biomass burning events were then defined as times when fire radiative power was larger than its overall third quantile and CO mixing ratios were at least $16 \mathrm{ppb}$ (expanded uncertainty of 1hourly data) larger than the background $\mathrm{CO}$ concentrations. The CO background was estimated using the Robust Extraction of Background Signal (REBS) method of Ruckstuhl et al. (2008) ${ }^{1}$ applying a tuning constant b of 3.5, a 60 day window width and the "residuals below the mode" scaling function. All night-time $\mathrm{CO}$ measurements, also at times excluded for the climatological analysis, were used. Of the selected times only continuous periods with at least 12 data points (which is equivalent to 1.5 days due to the use of night-time data only) were kept for regression analysis. Estimated correlation coefficients further had to satisfy $R^{2}>0.2$ and $p<0.01$.

With these criteria only 4 significant biomass burning events remained within the four year period, again underlining the baseline character of the MKN site. For the detected events quantitative backward dispersion simulations using the Lagrangian particle dispersion model FLEXPART (Stohl et al., 2005) were performed. With these it was possible to estimate the age of the pollution plumes from the time along the simulation when fire radiative power was "pickedup". For the four events the slope of the $\mathrm{O}_{3}-\mathrm{CO}$ relationship ranged from $0.23 \pm 0.02$ to $0.67 \pm 0.23$, while the age of the plumes ranged from $3.7 \pm 0.5$ to $4.3 \pm 0.6$ and was estimated

\footnotetext{
${ }^{1}$ Ruckstuhl, A., Henne, S., Reimann, S., and Hüglin, C.: Estimation of background concentrations of atmospheric trace gases using robust local regression, Atmos. Chem. Phys. Discuss., in preparation, 2008.
} 

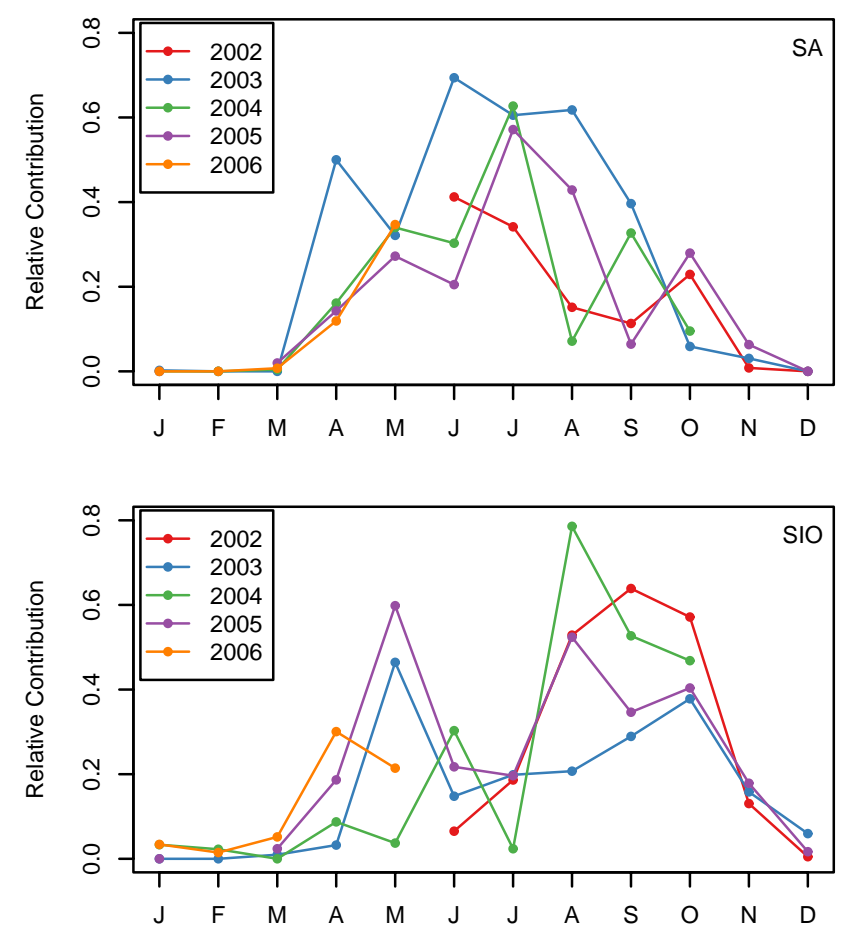

Fig. 10. Annual cycle of cluster contribution for different years for the South African cluster (SA, upper graph) and the Southern Indian Ocean cluster (SIO, lower graph).

with a relatively larger uncertainty (Fig. 11 and Table 4). Of the four detected events three were of northern hemispheric origin with pollutants being released from biomass burning in eastern Sudan and western Ethiopia, as is shown by the back trajectories overlayed on the fire count map for the most pronounced plume in February 2004 (Fig. 12). Note that this event was already identified as a pollution event in Sect. 3.1 and was therefore not included in the climatological analysis. The remaining plume was of southern hemispheric origin, carrying biomass burning emissions from Madagascar and northern Mozambique.

Our derived slopes agree well with estimates taken from flight campaigns near the southern African biomass burning region or over the tropical South Atlantic. As part of the CITE-3 flight campaign $\Delta \mathrm{O}_{3} / \Delta \mathrm{CO}$ enhancements in the range $0.2-0.7$ were observed for aged (7-10 d) biomass burning plumes (Andreae et al., 1994). During TRACE-A over southern Africa, South America and the South Atlantic, Mauzerall et al. (1998) derived $\Delta \mathrm{O}_{3} / \Delta \mathrm{CO}$ of $0.15 \pm 0.37$ for fresh biomass burning plumes $(<0.2 \mathrm{~d}), 0.32 \pm 0.76$ for recent plumes $(\leq 1 \mathrm{~d}), 0.71 \pm 0.12$ for aged plumes $(\leq 5 \mathrm{~d})$ and $0.74 \pm 0.9$ for old plumes $(>5 \mathrm{~d})$. They suggest a correction of about $-20 \%$ for older plumes due to loss of CO during transport.

During the SAFARI August/September 2000 experiment in southern Africa Yokelson et al. (2003) observed slopes of 0.09 in fresh $(<1 \mathrm{~h})$ biomass burning using airborne FTIR

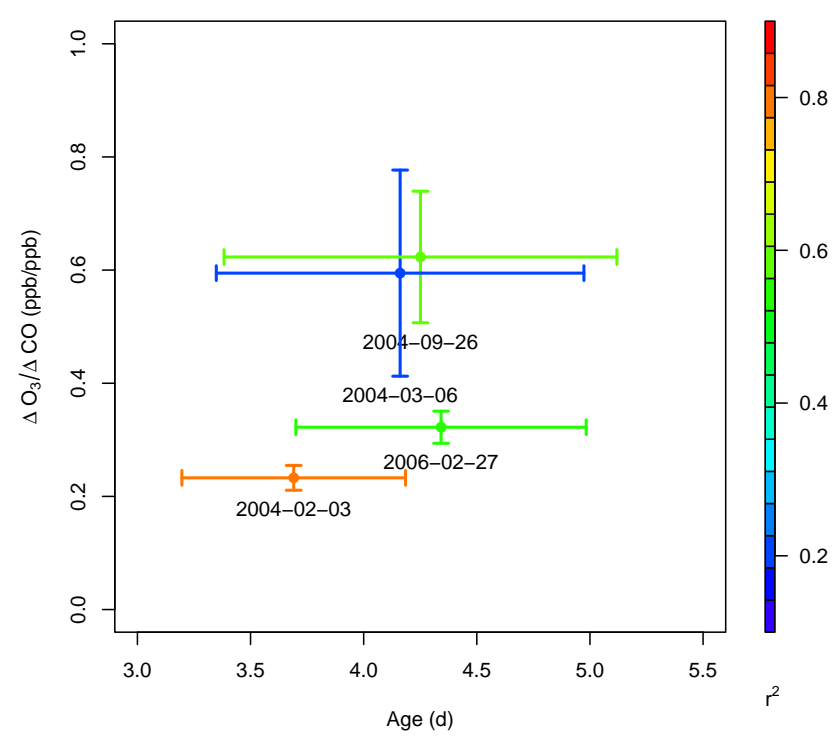

Fig. 11. $\mathrm{O}_{3}-\mathrm{CO}$ regression slope versus plume age for detected biomass burning events. Error bars represent the uncertainty $(p<0.05)$ of the slope and age, respectively. The given date marks the beginning of the pollution event.
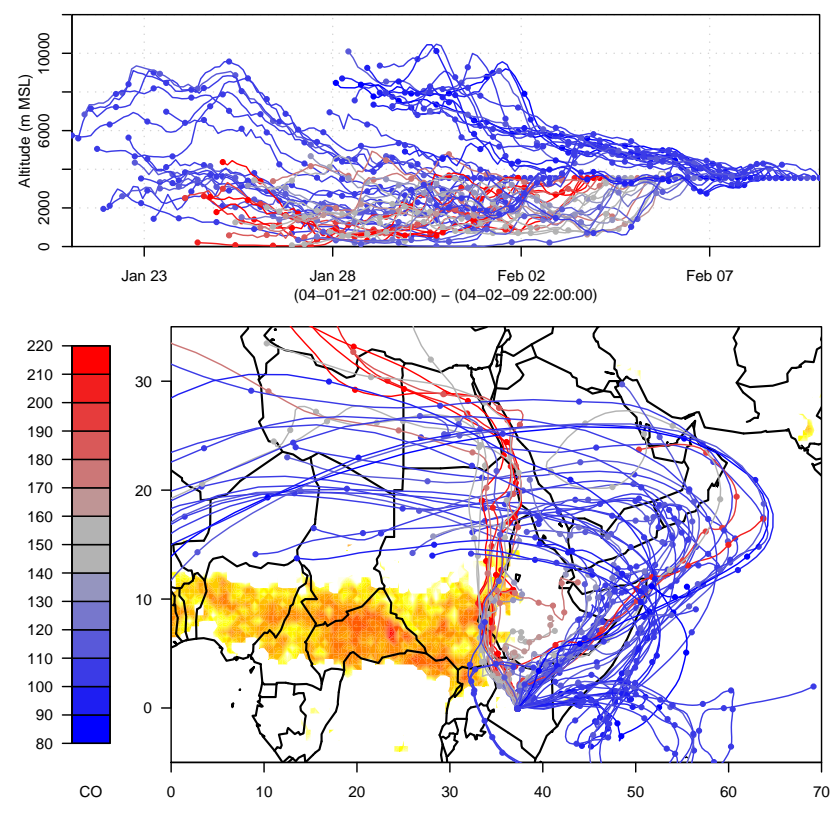

Fig. 12. Backward trajectories (colour refers to carbon monoxide concentration (ppb) measured at MKN) during a pollution event in February 2004. In addition, MODIS fire counts, totalled for the same period, are indicated in red shades for large and yellow shades for small fire count density. The map is left blank where no fires were detected.

measurements. This slope increased to 0.22 for biomass burning haze age of 2-4 days. For the same campaign, detailed information of the evolution of $\Delta \mathrm{O}_{3} / \Delta \mathrm{CO}$ in biomass 

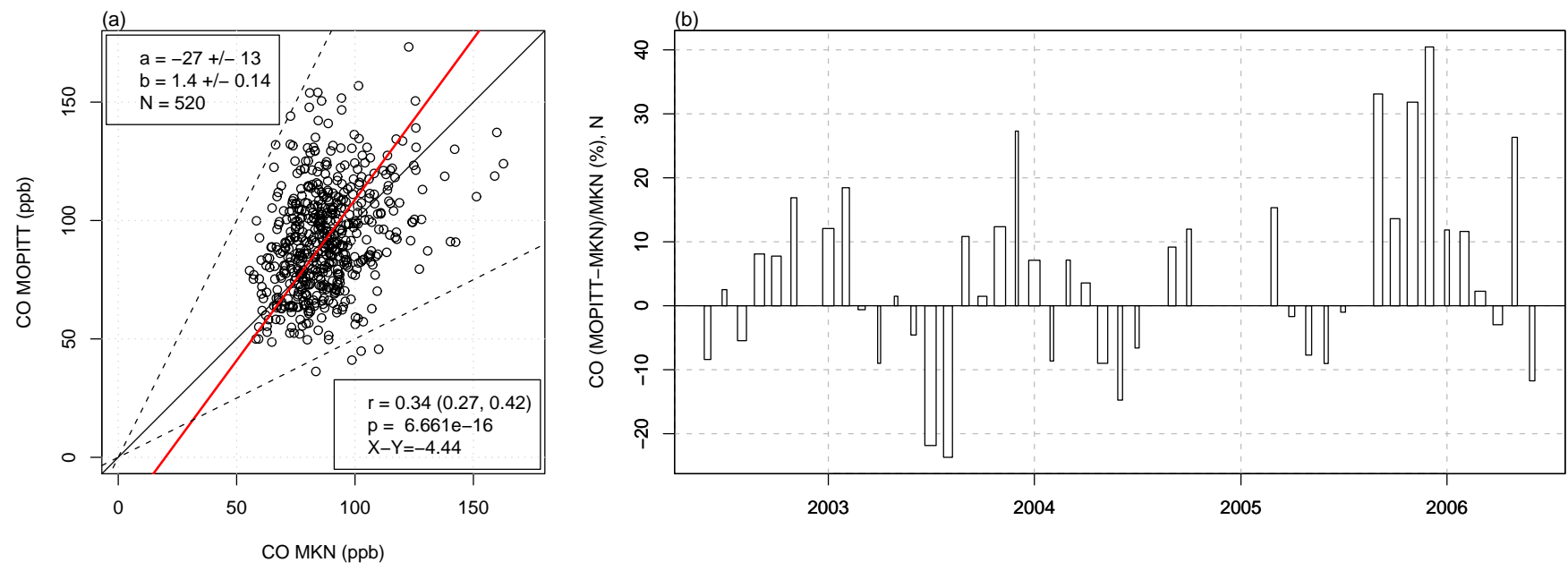

Fig. 13. Inter-comparison of $\mathrm{CO}$ at $\mathrm{MKN}$ versus $\mathrm{CO}$ from MOPITT, (a) regression plot of individual concurrent measurements (the red line refers to the regression line using the Press et al. (1992) method, the black line is the 1:1 line and the black dashed lines indicate a slope of 2 and 0.5 , respectively), (b) relative differences of MOPITT CO compared to MKN CO on a monthly basis, the width of the bars is proportional to thenumber of measurements in the monthly mean (the most narrow bars correspond to 1 the widest bars to 19 samples).

burning plumes observed over Namibia is given by Jost et al. (2003). $\Delta \mathrm{O}_{3} / \Delta \mathrm{CO}$ increased from 0.07 at $1 \mathrm{~h}$ after the emission to 0.1 after $2 \mathrm{~h}$. Model simulations successfully reproduced the $\mathrm{O}_{3}$ measurements. For fresh $(<0.5 \mathrm{~d})$ biomass burning plumes in northern Australia during the 1999 BIBLE-B experiment Takegawa et al. (2003) estimated a $\Delta \mathrm{O}_{3} / \Delta \mathrm{CO}$ slope of $0.12 \pm 0.04$. For average vertical profiles of $\mathrm{CO}$ as obtained by MOPITT and $\mathrm{O}_{3}$ from sondes, Bremer et al. (2004) derived a fractional increase of $\Delta \mathrm{O}_{3} / \Delta \mathrm{CO}$ of $0.2-0.4$ from May to October over Natal, Brazil. During PEM-Tropics-A over the remote South Pacific $\Delta \mathrm{O}_{3} / \Delta \mathrm{CO}$ slope was determined to be 0.75 in three plumes of aged biomass burning pollutants originating in southern Africa and northern Australia (Singh et al., 2000).

A clear tendency towards larger slopes for more aged plumes could not be deduced from our data. One reason might be that all observed pollution plumes were of similar age. No fresh or very aged plumes were detected. The $\mathrm{O}_{3}$ $\mathrm{CO}$ relationship furthermore depends on the emission profiles of ozone precursors. These can vary drastically for different types of biomass burning. Especially the $\mathrm{NO}_{\mathrm{x}}$ to $\mathrm{CO}$ emission ratio changes strongly from high values for intensive well-ventilated Savannah fires to low values for smoldering fires typical for more dense and moister vegetation. These conditions might not only vary by region but also interannually, depending on the amount of precipitation available within the last growing season.

\subsection{Comparison with other measurements}

To further support our findings on the representativeness of the MKN measurements, these were compared directly to satellite and other in-situ observations in eastern Africa.

\subsubsection{MOPITT CO}

Our CO measurements at MKN were compared to satelliteretrieved $\mathrm{CO}$ obtained from the Measurement of Pollution in the Troposphere (MOPITT) instrument onboard NASA satellite Terra (Deeter et al., 2003; Edwards et al., 2006a) at $700 \mathrm{hPa}$. Previous inter-comparisons between MOPITT and in situ profiles showed good agreement, with the bias mean and standard deviation for the retrieved $\mathrm{CO}$ column being $-0.5 \pm 12.1 \%$ (Emmons et al., 2004; Deeter et al., 2003). MOPITT $700 \mathrm{hPa}$ monthly means for the lower southern hemisphere $\left(0-30^{\circ} \mathrm{S}\right)$ were compared with $\mathrm{CO}$ from the NOAA ESRL flask sampling network (Edwards et al., 2006b). MOPITT measurements were clearly larger than in-situ measurements, most likely due to different sampling altitudes and different geographic representation. The overpass time of the satellite is about 10:30 a.m/p.m UTC. Since retrievals are sparse in this equatorial region (max. distance between swaths at the equator and persistent clouds) it was necessary to use retrieved pixels within a radius of $200 \mathrm{~km}$ around the site and use dayand night-time data to derive a reasonable daily average. Day and night-time data showed little differences. A maximal a priori fraction of $60 \%$ was allowed. To avoid any influence by up-slope flow only $\mathrm{CO}$ measurements at MKN from 00:00 to 04:00 UTC and from 21:00 to 23:00 were used to derive a daily average that was compared to the satellite retrieved daily averages. For 520 days both time series were available. A regression analysis resulted in $[\mathrm{CO}]_{\mathrm{MOPITT}}=1.4( \pm 0.14)[\mathrm{CO}]_{\mathrm{MKN}}-27( \pm 14)[\mathrm{ppb}]$, 

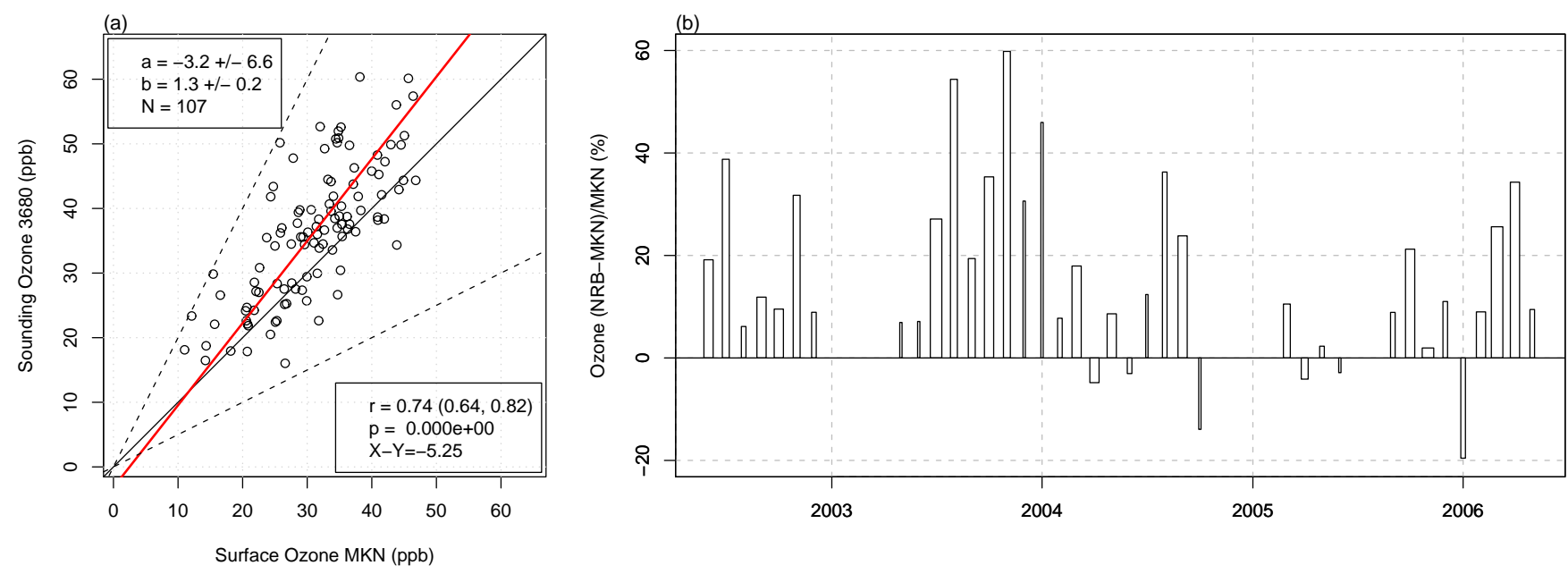

Fig. 14. Inter-comparison of $\mathrm{O}_{3}$ at $\mathrm{MKN}$ versus $\mathrm{O}_{3}$ from $\mathrm{O}_{3}$ soundings at Nairobi, (a) regression plot of individual concurrent measurements at station altitude, $3680 \mathrm{~m}$ a.s.l. (the red line refers to the regression line using the Press et al. (1992) method, the black line is the 1:1 line and the black dashed lines indicate a slope of 2 and 0.5, respectively), (b) relative differences of sounding $\mathrm{O}_{3}$ at station altitude compared to $\mathrm{MKN} \mathrm{O}_{3}$ on a monthly basis, the width of the bars is proportional to the number of measurements in the monthly mean (the most narrow bars correspond to 1 the widest bars to 5 samples).

$R^{2}=0.1, n=520$ (Fig. 13a). The low correlation is reflected by large scatter of the points around the 1:1 line. However, almost all MOPITT retrievals show deviations of less than a factor of 2 from the in-situ measurements. Possible reasons for the weak correlation are the horizontal and vertical differences in the sampled volume of air and uncertainties in the a priori profile used in the retrieval.

On a monthly basis, the agreement between MKN and MOPITT measurements was mostly within $\pm 15 \%$ (Fig. 13b), which is reasonable when considering the different horizontal and vertical scales involved. Nevertheless two periods of larger differences can be identified: July/August 2003 when a negative bias of the satellite data is observed and September to December 2005 with a positive bias. The first period coincides with a period of increased southerly advection of more polluted air masses from the south African subcontinent (compare also Sect. 3.5). It is likely that biomass burning plumes were advected within the boundary layer and in isolated elevated layers in the lower troposphere that were not well represented in the satellite retrievals. Additional, small scale biomass burning closer to the site might have contributed to isolated plumes that reached MKN at times but were not detected by the satellite. For the even larger discrepancies in late 2005 no sound explanation could be found. It is possible that enhanced $\mathrm{CO}$ mixing ratios were advected from the northern hemisphere towards Kenya at altitudes above the altitude of MKN and that the site itself was influenced by air of more maritime origin that was depleted in CO. However, there is little evidence for changes in advection towards $\mathrm{MKN}$ in comparison to other years when no systematic discrepancies between MKN and MOPITT were observed.

\subsection{2 $\mathrm{SHADOZ} \mathrm{O}_{3}$}

Regular $\mathrm{O}_{3}$ observations close to MKN are performed in the context of the SHADOZ programme at Nairobi, about $150 \mathrm{~km}$ south-west of MKN (Thompson et al., 2004). A total of $212 \mathrm{O}_{3}$ soundings were available for the period investigated (June 2002 to June 2006) and for 107 soundings the corresponding $\mathrm{O}_{3}$ measurements were available from MKN. Soundings were usually started between 07:00 and 10:00 UTC. Since the MKN site might already be influenced by up-slope flow at this time of the day, $\mathrm{MKN} \mathrm{O}_{3}$ measurements of the preceding night (21:00-04:00 UTC) were compared with the sounding results within a $250 \mathrm{~m}$ thick layer centred at the station altitude. The ENSCI-Z ozone sondes employed in Nairobi use the electrochemical concentration cell (ECC) principle and are prepared with $1 \% \mathrm{KI}$. Different ozone sonde inter-comparisons within the last 10 years have shown that this sonde and solution type overestimates $\mathrm{O}_{3}$ by 3-9\% in the lower troposphere (see Fig. 10a in Smit et al., 2007). We therefore applied an average correction of $6 \%$ to the Nairobi soundings before comparing them with the MKN measurements at station altitude.

Linear regression yielded $\left[\mathrm{O}_{3}\right]_{\text {sounding }}=$ $1.3( \pm 0.2)\left[\mathrm{O}_{3}\right]_{\mathrm{MKN}}-3( \pm 7)[\mathrm{ppb}], \quad R^{2}=0.55, \quad n=107$ (Fig. 14a). Most points lie above the 1:1 line and for some soundings the differences are more than a factor of 2. Comparison of the means indicated an average absolute difference of $\left[\mathrm{O}_{3}\right]_{\mathrm{MKN}}-\left[\mathrm{O}_{3}\right]_{\text {sounding }}=-5 \mathrm{ppb}$. These results did not improve when MKN measurements of the time 
of the sounding or night-time measurements from 01:00 to 04:00 UTC were used. The relative difference of the sounding data compared to the ground-based data on a monthly basis (Fig. 14b) shows mostly positive deviations that can reach up to $60 \%$, while months with negative deviations (maximum 20\%) were rare. Furthermore, a period with especially enhanced sounding $\mathrm{O}_{3}$ ranging from August 2003 to January 2004 was identified. An indication for this discrepancy could neither be found in the calibration of the $\mathrm{MKN}_{3}$ monitor nor in the Nairobi $\mathrm{O}_{3}$ calibrator. One possible reason could be an additional offset of a certain batch of sondes used during this period. Next to the uncertainty in the absolute calibration of the measurements, especially the correction of the sounding $\mathrm{O}_{3}$, three processes might be responsible for the systematically higher $\mathrm{O}_{3}$ of the soundings: $\mathrm{O}_{3}$ surface deposition in shallow nocturnal mountain boundary layers before the air reaches $\mathrm{MKN}$, dynamic lifting of the air mass when it approaches the Mt. Kenya massif and local photochemical production of $\mathrm{O}_{3}$ in the Nairobi city plume.

To investigate the influence of the first process we calculated the $\mathrm{O}_{3}$ deposition depending on the height of the nocturnal mountain boundary layer and the travel distance in such a layer before reaching MKN. At night the main flow direction at MKN was down-slope with an average velocity of $5 \mathrm{~ms}^{-1}$. It is therefore reasonable to assume that the sampled air mass was not in contact with the forest belt, which is $500 \mathrm{~m}$ below the site and where increased $\mathrm{O}_{3}$ deposition would be expected, and was therefore only exposed to grassland. We used a typical $\mathrm{O}_{3}$ deposition velocity for grassland of $0.1 \mathrm{cms}^{-1}$ (e.g., Pio et al., 2000). With these assumptions a considerable $(>10 \%) \mathrm{O}_{3}$ deposition could only be reached for very shallow $(<20 \mathrm{~m})$ boundary layers and long advection distances along the slope $(>8 \mathrm{~km})$. While the latter condition corresponds to the distance from the site to the first crests of the Mt. Kenya peak area, the first condition might only be met close to the crest of a slope but not further downhill since the depth of the nocturnal drainage flow usually increases with along-slope distance (Whiteman, 1990). We therefore conclude that $\mathrm{O}_{3}$ deposition in nocturnal boundary layer flow along the mountain slope is of minor importance and cannot account for the large differences observed between sounding and ground-based data.

To investigate the possible influence of dynamic lifting on the MKN measurements we compared sounding data from different altitude ranges $(250 \mathrm{~m}$ bins) to the ground-based data. The best agreement in terms of 1:1 slope of the regression line was observed for an altitude range centered around $2930 \mathrm{~m}$ a.s.l. with a slope of $1 \pm 0.2$. However, the correlation for this altitude was considerably lower than for the inter-comparison at station altitude $\left(r^{2}=0.44\right)$. Furthermore, potential temperatures at MKN compared best with the sounding measurements at station altitude (not shown), indicating no substantial adiabatic lifting of the air before reaching MKN. Due to the large diurnal temperature amplitude at MKN, early morning measurements (04:00-05:00 UTC) were used for the comparison because no thermally-driven winds are observed during this period, which underlines that the temperature along the slope was similar to the temperature in the local free troposphere. Both arguments weaken the conclusion that measurements at MKN might be more representative of an altitude of $2930 \mathrm{~m}$ a.s.l. instead of the station altitude.

No direct observation of local photochemical production of $\mathrm{O}_{3}$ in the Nairobi city plume can be presented here. However, the Nairobi metropolitan area comprises about 4 million inhabitants with a strongly increasing demand for transportation. A large number of vehicles is in poor working condition and operated without any emission control. Therefore, $\mathrm{NO}_{\mathrm{x}}$ emissions are expected to be substantial within the bonds of the city. Under dry and strong irradiation conditions prevailing in Kenya, $\mathrm{O}_{3}$ will be readily formed from $\mathrm{NO}_{\mathrm{x}}$ and volatile organic compounds and mixed within the convective boundary layer up to about $4 \mathrm{~km}$ a.s.l. (Henne et al., 2008). Since the $\mathrm{O}_{3}$ sondes are launched only a few kilometers from the city center and then drift with the main wind within the city plume, the sounding measurements in the lowest kilometers of the troposphere are more representative of urban air masses than of rural background conditions as observed at MKN. The local pollution in the Nairobi city plume is therefore thought to be the main contributor to the systematically lower $\mathrm{O}_{3}$ observations at $\mathrm{MKN}$.

\section{Conclusions}

Because the Mt. Kenya GAW station is situated in eastern equatorial Africa it is largely unaffected by direct African biomass burning emissions that are most prominent in the western parts of the continent but insignificant in Kenya. The local environment of the Mt. Kenya site is in general free of anthropogenic emissions and makes atmospheric baseline measurements possible. For only $2 \%$ of all sampled times did local wildfire emissions influence the measurements directly. These events can easily be detected and removed from data analysis and therefore do not disturb the baseline character of the station. At the high altitude site night-time (21:0004:00 UTC) measurements were in general more representative of FT conditions, while day-time measurements were influenced by the ABL throughout the whole year and under different synoptic conditions, rendering day-time measurements not appropriate for atmospheric baseline estimation. The measurements at Mt. Kenya were found to be representative of six different catchment areas at different times of the year: eastern Africa throughout the whole year $(21 \%)$, continental northern hemispheric air originating over the Arabian Peninsula and Pakistan throughout the whole year $(16 \%)$, northern hemispheric free tropospheric background from January to May (6\%), northern hemispheric air originating over India and crossing the northern Indian 
Ocean from November to April (17\%), continental southern hemispheric air originating in south-eastern Africa from April to October (18\%) and southern Indian Ocean maritime air from April to November (21\%).

The average overall night-time $\mathrm{CO}$ mixing ratio at MKN was $94 \pm 16 \mathrm{ppb}$. The $\mathrm{CO}$ annual cycle with two maxima in February and August indicates the influence of the oscillating monsoon circulation. The winter/spring maximum was caused by advection of northern hemispheric air that is enriched in $\mathrm{CO}$ during the boreal winter. In contrast, the summer maximum was observed during advection of southern hemispheric air loaded with emissions from biomass burning in southern Africa. Peak CO concentrations in the southern African biomass burning regions occur later (August/September) than at MKN. However, direct northward transport ceases when concentrations are maximal in southern Africa. Inter-annual variability in summer time $\mathrm{CO}$ could mostly be explained by a combination of changes in transport patterns and biomass burning intensity. The average overall night-time $\mathrm{O}_{3}$ mixing ratio at MKN was $29 \pm 3 \mathrm{ppb}$. The annual cycle of $\mathrm{O}_{3}$ was less pronounced than the one of $\mathrm{CO}$. Mixing ratios were highest during the southern hemisphere biomass burning season from July to September and reached a minimum during the southward passage of the ITCZ during November.

The measurements at MKN are representative of air masses with little photochemical activity as indicated by weak $\mathrm{O}_{3}-\mathrm{CO}$ correlations. The strongest correlations were found in air masses originating from the remote southern Indian Ocean, indicative of photochemical destruction. On the one hand, these weak $\mathrm{O}_{3}-\mathrm{CO}$ correlations and the infrequent number of pollution events prove the baseline character of the station, on the other hand, the station is sometimes influenced by biomass burning events and can therefore be used as a platform to study aged biomass burning plumes. Biomass burning plumes observed at the site were between 3 to 5 days old and showed a strong $\mathrm{O}_{3}$-CO correlation with slopes increasing from 0.2 after 3 days to 0.6 after 5 days.

The inter-comparison of ground-based $\mathrm{O}_{3}$ measurements at MKN with sounding data over Nairobi revealed a positive bias of the latter. Next to the uncertainties involved in the inter-comparison of two point measurements more than $100 \mathrm{~km}$ apart from each other and with a limited number of samples, three atmospheric processes could be responsible for the bias. Ozone dry deposition close to the surface site and general lifting of an air mass when it approaches the Mt. Kenya massif could be ruled out by estimating dry deposition in the grassland environment of the MKN site and by comparing potential temperatures at the site and from the soundings. Additional photochemical production of $\mathrm{O}_{3}$ in the Nairobi city plume was determined to be the main cause of the positive deviation of the sounding data from the ground-based observations at the same altitude.

The MKN GAW station is a very promising site for future studies of atmospheric chemistry in the equatorial western
Indian Ocean and eastern Africa. The location of the site within the strong monsoonal currents crossing the Equator along the eastern edge of the African continent would allow for studies of inter-hemispheric exchange. The expansion of the ongoing measurement program will promote our understanding of the atmospheric chemistry over the remote Indian Ocean and eastern Africa. Future trend analysis will show the influence of increasing Asian emissions on the marine environment of the Indian Ocean.

Acknowledgements. We gratefully acknowledge the financial support of MeteoSwiss. The establishment of the Mt. Kenya GAW station was supported by the World Bank through their Global Environmental Facility. We would like to thank David Edwards for providing the MOPITT time series for the location of Mt. Kenya. The ozone sounding data from Nairobi were provided by Bertrand Calpini within the SHADOZ programme. We thank the authorities of the Mount Kenya National Park for their cooperation and the local technicians and workers for their work under often difficult conditions.

Edited by: A. Pszenny

\section{References}

Aghedo, A. M., Schultz, M. G., and Rast, S.: The influence of African air pollution on regional and global tropospheric ozone, Atmos. Chem. Phys., 7, 1193-1212, 2007, http://www.atmos-chem-phys.net/7/1193/2007/.

Andreae, M. O. and Merlet, P.: Emission of trace gases and aerosols from biomass burning, Glob. Biogeochem. Cy., 15, 955-966, 2001.

Andreae, M. O., Anderson, B. E., Blake, D. R., Bradshaw, J. D., Collins, J. E., Gregory, G. L., Sachse, G. W., and Shipham, M. C.: Influence of Plumes from Biomass Burning on Atmospheric Chemistry over the Equatorial and Tropical SouthAtlantic during Cite-3, J. Geophys. Res.-Atmos., 99, 12 793$12808,1994$.

Asnani, G.: Tropical Meteorology, Volume 1, Noble Printers, Pune, India, 1993.

Brankov, E., Rao, S. T., and Porter, P. S.: A trajectory-clusteringcorrelation methodology for examining the long-range transport of air pollutants, Atmos. Environ., 32, 1525-1534, 1998.

Bremer, H., Kar, J., Drummond, J. R., Nichitu, F., Zou, J. S., Liu, J., Gille, J. C., Deeter, M. N., Francis, G., Ziskin, D., and Warner, J.: Spatial and temporal variation of MOPITT CO in Africa and South America: A comparison with SHADOZ ozone and MODIS aerosol, J. Geophys. Res.-Atmos., 109, D12, doi:10.1029/2003JD004234, 2004.

Chameides, W. and Walker, J. C. G.: Photochemical Theory of Tropospheric Ozone, J. Geophys. Res., 78, 8751-8760, 1973.

Chatfield, R. B. and Delany, A. C.: Convection Links Biomass Burning to Increased Tropical Ozone - However, Models Will Tend to Overpredict O3, J. Geophys. Res. Atmos., 95, $18473-$ 18 488, 1990.

Crutzen, P. J.: Photochemical reaction initiated by and influencing ozone in unpolluted tropospheric air, Tellus, 26, 45-55, 1974. 
Crutzen, P. J. and Andreae, M. O.: Biomass Burning in the Tropics Impact on Atmospheric Chemistry and Biogeochemical Cycles, Science, 250, 1669-1678, 1990.

de Gouw, J. A., Warneke, C., Scheeren, H. A., van der Veen, C., Bolder, M., Scheele, M. P., Williams, J., Wong, S., Lange, L., Fischer, H., and Lelieveld, J.: Overview of the trace gas measurements on board the Citation aircraft during the intensive field phase of INDOEX, J. Geophys. Res. Atmos., 106, 28453 28 467, 2001.

de Laat, A. T. J., Lelieveld, J., Roelofs, G. J., Dickerson, R. R., and Lobert, J. M.: Source analysis of carbon monoxide pollution during INDOEX 1999, J. Geophys. Res. Atmos., 106, 28 48128 495, 2001.

Deeter, M. N., Emmons, L. K., Francis, G. L., Edwards, D. P., Gille, J. C., Warner, J. X., Khattatov, B., Ziskin, D., Lamarque, J. F., Ho, S. P., Yudin, V., Attie, J. L., Packman, D., Chen, J., Mao, D., and Drummond, J. R.: Operational carbon monoxide retrieval algorithm and selected results for the MOPITT instrument, J. Geophys. Res. Atmos., 108, 4399, doi:10.1029/202JD003186, 2003.

Dorling, S. R., Davies, T. D., and Pierce, C. E.: Cluster-Analysis - a Technique for Estimating the Synoptic Meteorological Controls on Air and Precipitation Chemistry - Method and Applications, Atmos. Environ.,Part a-General Topics, 26, 2575-2581, 1992a.

Dorling, S. R., Davies, T. D., and Pierce, C. E.: Cluster-Analysis - a Technique for Estimating the Synoptic Meteorological Controls on Air and Precipitation Chemistry - Results from Eskdalemuir, South Scotland, Atmos. Environ., Part a-General Topics, 26, 2583-2602, 1992b.

Edwards, D. P., Emmons, L. K., Gille, J. C., Chu, A., Attié, J.-L., Giglio, L., Wood, S. W., Haywood, J., Deeter, M. N., Massie, S. T., Ziskin, D., and Drummond, J. R.: Satellite-observed pollution from Southern Hemisphere biomass burning, J. Geophys. Res., 111, D14312, doi:10.1029/2005JD006655, 2006a.

Edwards, D. P., Petron, G., Novelli, P. C., Emmons, L. K., Gille, J. C., and Drummond, J. R.: Southern Hemisphere carbon monoxide interannual variability observed by Terra/Measurement of Pollution in the Troposphere (MOPITT), J. Geophys. Res. Atmos., 111, D16303, doi:10.1029/ 2006JD007079, 2006b.

Emmons, L. K., Deeter, M. N., Gille, J. C., Edwards, D. P., Attie, J. L., Warner, J., Ziskin, D., Francis, G., Khattatov, B., Yudin, V., Lamarque, J. F., Ho, S. P., Mao, D., Chen, J. S., Drummond, J., Novelli, P., Sachse, G., Coffey, M. T., Hannigan, J. W., Gerbig, C., Kawakami, S., Kondo, Y., Takegawa, N., Schlager, H., Baehr, J., and Ziereis, H.: Validation of Measurements of Pollution in the Troposphere (MOPITT) CO retrievals with aircraft in situ profiles,J. Geophys. Res. Atmos., 109, D03309, doi: 10.1029/2003JD004101, 2004.

Findlater, J.: A Major Low-Level Air Current near Indian Ocean during Northern Summer, Q. J. Roy. Meteorol. Soc., 95, 362380, 1969.

Fishman, J. and Seiler, W.: Correlative Nature of Ozone and Carbon-Monoxide in the Troposphere - Implications for the Tropospheric Ozone Budget, J. Geophys. Res.-Oceans, 88, 36623670, 1983.

Fishman, J., Solomon, S., and Crutzen, P. J.: Observational and Theoretical Evidence in Support of a Significant Insitu PhotoChemical Source of Tropospheric Ozone, Tellus, 31, 432-446, 1979.
Fishman, J., Hoell, J. M., Bendura, R. D., McNeil, R. J., and Kirchhoff, V. W. J. H.: NASA GTE TRACE A experiment (September October 1992): Overview, J. Geophys. Res. Atmos., 101, 23 865-23 879, 1996.

Garstang, M., Tyson, P. D., Swap, R., Edwards, M., Kallberg, P., and Lindesay, J. A.: Horizontal and vertical transport of air over southern Africa, J. Geophys. Res. Atmos., 101, 23 721-23 736, 1996.

Gatebe, C., Tyson, P., Annegarn, H., Piketh, S., and Helas, G.: A seasonal air transport climatology for Kenya, J. Geophys. Res. Atmos., 104, 14 237-14 244, 1999.

Giglio, L., Csiszar, I., and Justice, C. O.: Global distribution and seasonality of active fires as observed with the Terra and Aqua Moderate Resolution Imaging Spectroradiometer (MODIS) sensors, J. Geophys. Res., 111, doi:10.1029/2005JG000142, 2006.

Harris, J. M. and Kahl, J. D.: A Descriptive Atmospheric Transport Climatology for the Mauna-Loa-Observatory, Using Clustered Trajectories, J. Geophys. Res. Atmos., 95, 13 651-13667, 1990.

Henne, S., Junkermann, W., Klausen, J., Kariuki, J. M., and Aseyo, J.: The Establishment of the Mt. Kenya GAW Station: Installation and Meteorological Characterization, J. Appl. Meteorol. Clim., in press, 2008.

IPCC: Climate Change 2001: The Scientific Basis. Contribution of Working Group I to the Third Assessment Report of the Intergovernmental Panel on Climate Change, Cambridge Univeristy Press, Cambridge, UK and New York, USA, 2001.

ISO: 11222:2002 Air quality - Determination of the uncertainty of the time average of air quality measurements, Tech. Rep. 11222:2002, International Organization for Standardization (ISO), 2002.

Jost, C., Trentmann, J., Sprung, D., Andreae, M. O., McQuaid, J. B., and Barjat, H.: Trace gas chemistry in a young biomass burning plume over Namibia: Observations and model simulations, J. Geophys. Res. Atmos., 108, D13, 8482, doi:10.1029/2002JD002431, 2003.

Justice, C. O., Giglio, L., Korontzi, S., Owens, J., Morisette, J. T., Roy, D., Descloitres, J., Alleaume, S., Petitcolin, F., and Kaufman, Y.: The MODIS fire products, Remote Sens. Environ., 83, 244-262, 2002.

Kaufman, L. and Rousseeuw, P.: Finding Groups in Data. An Introduction to Cluster Analysis, John Wiley and Sons, New York, 342 pp., 1990.

Klausen, J., Zellweger, C., Buchmann, B., and Hofer, P.: Uncertainty and bias of surface ozone measurements at selected Global Atmosphere Watch sites, J. Geophys. Res. Atmos., 108, 4622, doi:10.1029/2003JD003710, 2003.

Klausen, J., Henne, S., Zellweger, C., and Buchmann, B.: System and Performance Audit for Surface Ozone an Carbon Monoxide at the Global GAW Station Mt. Kenya, Tech. rep., Empa-WCC, 2006.

Klonecki, A. and Levy, H.: Tropospheric chemical ozone tendencies in CO-CH4-NOy-H2O system: Their sensitivity to variations in environmental parameters and their application to a global chemistry transport model study, J. Geophys. Res. Atmos., 102, 21 221-21 237, 1997.

Lelieveld, J. and Dentener, F. J.: What controls tropospheric ozone?, J. Geophys. Res. Atmos., 105, 3531-3551, 2000.

Lelieveld, J., Crutzen, P. J., Ramanathan, V., Andreae, M. O., Bren- 
ninkmeijer, C. A. M., Campos, T., Cass, G. R., Dickerson, R. R., Fischer, H., de Gouw, J. A., Hansel, A., Jefferson, A., Kley, D., de Laat, A. T. J., Lal, S., Lawrence, M. G., Lobert, J. M., MayolBracero, O. L., Mitra, A. P., Novakov, T., Oltmans, S. J., Prather, K. A., Reiner, T., Rodhe, H., Scheeren, H. A., Sikka, D., and Williams, J.: The Indian Ocean Experiment: Widespread air pollution from South and Southeast Asia, Science, 291, 1031-1036, 2001.

Leroux, M.: The meteorology and climate of tropical Africa, Springer, 548 pp., London, 2001.

Levy, H.: Normal Atmosphere - Large Radical and Formaldehyde Concentrations Predicted, Science, 173, 141-143, 1971.

Lindesay, J. A., Andreae, M. O., Goldammer, J. G., Harris, G., Annegarn, H. J., Garstang, M., Scholes, R. J., and vanWilgen, B. W.: International Geosphere-Biosphere Programme International Global Atmospheric Chemistry SAFARI-92 field experiment: Background and overview, J. Geophys. Res. Atmos., 101, 23 521-23 530, 1996.

Loader, C.: Local regression and likelihood, Springer, New York, 290pp., 1999.

Logan, J. A., Prather, M. J., Wofsy, S. C., and Mcelroy, M. B.: Tropospheric Chemistry - a Global Perspective, J. Geophys.Res.Ocean, 86, 7210-7254, 1981.

Marenco, A., Thouret, V., Nédélec, P., Smit, H., Helten, M., Kley, D., Karcher, F., Simon, P., Law, K., Pyle, J., Poschmann, G., Von Wrede, R., Hume, C., and Cook, T.: Measurement of ozone and water vapor by Airbus in-service aircraft: The MOZAIC airborne program, An overview, J. Geophys. Res. Atmos., 103, 25 631-25 642, 1998.

Martin, R. V., Jacob, D. J., Logan, J. A., Bey, I., Yantosca, R. M., Staudt, A. C., Li, Q. B., Fiore, A. M., Duncan, B. N., Liu, H. Y., Ginoux, P., and Thouret, V.: Interpretation of TOMS observations of tropical tropospheric ozone with a global model and in situ observations, J. Geophys. Res. Atmos., 107, 4351, doi: 10.1029/2001JD001480, 2002.

Marufu, L., Dentener, F., Lelieveld, J., Andreae, M. O., and Helas, G.: Photochemistry of the African troposphere: Influence of biomass-burning emissions, J. Geophys. Res. Atmos., 105, 14 513-14 530, 2000.

Mauzerall, D. L., Logan, J. A., Jacob, D. J., Anderson, B. E., Blake, D. R., Bradshaw, J. D., Heikes, B., Sachse, G. W., Singh, H., and Talbot, B.: Photochemistry in biomass burning plumes and implications for tropospheric ozone over the tropical South Atlantic J. Geophys. Res. Atmos., 103, 8401-8423, 1998.

Moody, J. L. and Galloway, J. N.: Quatifying the relationship between atmospheric transport and the chemical composition of precipitation on Bermuda, Tellus, 40B, 463-479, 1988.

Nédélec, P., Cammas, J. P., Thouret, V., Athier, G., Cousin, J. M., Legrand, C., Abonnel, C., Lecoeur, F., Cayez, G., and Marizy, C.: An improved infrared carbon monoxide analyser for routine measurements aboard commercial Airbus aircraft: technical validation and first scientific results of the MOZAIC III programme, Atmos. Chem. Phys., 3, 1551-1564, 2003, http://www.atmos-chem-phys.net/3/1551/2003/.

Newchurch, M. J., Liu, X., Kim, J. H., and Bhartia, P. K.: On the accuracy of Total Ozone Mapping Spectrometer retrievals over tropical cloudy regions, J. Geophys. Res. Atmos., 106, 32 31532 326, 2001.

Novelli, P., Masarie, K., and Lang, P.: Distribution and recent changes of carbon monoxide in the lower troposhere,J. Geophys. Res. Atmos., 103, 19015-19 033, 1998a.

Novelli, P. C., Connors, V. S., Reichle, H. G., Anderson, B. E., Brenninkmeijer, C. A. M., Brunke, E. G., Doddridge, B. G., Kirchhoff, V. W. J. H., Lam, K. S., Masarie, K. A., Matsuo, T., Parrish, D. D., Scheel, H. E., and Steele, L. P.: An internally consistent set of globally distributed atmospheric carbon monoxide mixing ratios developed using results from an intercomparison of measurements, J. Geophys. Res. Atmos., 103, 19 285-19293, 1998 b.

Novelli, P. C., Masarie, K. A., Lang, P. M., Hall, B. D., Myers, R. C., and Elkins, J. W.: Reanalysis of tropospheric CO trends: Effects of the 1997-1998 wildfires,J. Geophys. Res. Atmos., 108, 4464, doi:10.1029/2002JD003031, 2003.

Parrish, D. D., Holloway, J. S., Trainer, M., Murphy, P. C., Forbes, G. L., and Fehsenfeld, F. C.: Export of North American Ozone Pollution to the North Atlantic Ocean, Science, 259, 1436-1439, 1993.

Parrish, D. D., Trainer, M., Holloway, J. S., Yee, J. E., Warshawsky, M. S., Fehsenfeld, F. C., Forbes, G. L., and Moody, J. L.: Relationships between ozone and carbon monoxide at surface sites in the North Atlantic region, J. Geophys. Res. Atmos., 103, $13357-$ 13376, 1998.

Pickering, K. E., Thompson, A. M., Tao, W. K., Rood, R. B., McNamara, D. P., and Molod, A. M.: Vertical Transport by Convective Clouds - Comparisons of 3 Modeling Approaches, Geophys. Res. Lett., 22, 1089-1092, 1995.

Pio, C. A., Feliciano, M. S., Vermeulen, A. T., and Sousa, E. C.: Seasonal variability of ozone dry deposition under southern European climate conditions, in Portugal, Atmos. Environ., 34, 195-205, 2000.

Press, W. H., Teukolsky, S. A., Vetterling, W. T., and Flannery, B. P.: Numerical Recipes in C, The Art of Scientific Computing, Cambridge University Press, Cambridge, UK, 2nd edn., 1992.

R Development Core Team: R 2.2.1: A language and environment for statistical computing, R Foundation for Statistical Computing, http://www.R-project.org, 2005.

Redelsperger, J. L., Thorncroft, C. D., Diedhiou, A., Lebel, T., Parker, D. J., and Polcher, J.: African monsoon multidisciplinary analysis - An international research project and field campaign, Bull. Am. Meteorol. Soc., 87, doi:10.1175/BAMS-87-12-1739, 2006.

Roberts, G., Wooster, M. J., Perry, G. L. W., Drake, N., Rebelo, L. M., and Dipotso, F.: Retrieval of biomass combustion rates and totals from fire radiative power observations: Application to southern Africa using geostationary SEVIRI imagery, J. Geophys. Res. Atmos., 110, D21111, doi:10.1029/2005JD006018, 2005.

Saraf, N., Beig, G., and Schultz, M.: Tropospheric distribution of ozone and its precursors over the tropical Indian Ocean, J. Geophys. Res. Atmos., 108, 4636, doi:10.1029/2003JD003521, 2003.

Sauvage, B., Thouret, V., Cammas, J. P., Gheusi, F., Athier, G., and Nédélec, P.: Tropospheric ozone over Equatorial Africa: regional aspects from the MOZAIC data, Atmos. Chem. Phys., 5, 311335,2005 , http://www.atmos-chem-phys.net/5/311/2005/.

Scholes, M. C., Matrai, P. A., Andreae, M. O., Smith, K. A., and Manning, M. R.: Biosphere-Atmosphere Interactions, in: Atom- 
spheric Chemistry in a Changing World, edited by: Brasseur, G., Prinn, R. G., and Pszenny, A., 19-71, Springer, Berlin, 2003.

Silva, J. M. N., Pereira, J. M. C., Cabral, A. I., Sa, A. C. L., Vasconcelos, M. J. P., Mota, B., and Gregoire, J. M.: An estimate of the area burned in southern Africa during the 2000 dry season using SPOT-VEGETATION satellite data,J. Geophys. Res. Atmos., 108, 8498, doi:10.1029/2002JD002320, 2003.

Singh, H. B., Viezee, W., Chen, Y., Bradshaw, J., Sandholm, S., Blake, D., Blake, N., Heikes, B., Snow, J., Talbot, R., Browell, E., Gregory, G., Sachse, G., and Vay, S.: Biomass burning influences on the composition of the remote South Pacific troposphere: analysis based on observations from PEM-Tropics-A, Atmos. Environ., 34, 635-644, 2000.

Slingo, J., Spencer, H., Hoskins, B., Berrisford, P., and Black, E.: The meteorology of the Western Indian Ocean, and the influence of the east African highlands, Philos. T. Roy. Soc. A, 363, 25-42, 2005.

Smit, H. G. J., Straeter, W., Johnson, B. J., Oltmans, S. J., Davies, J., Tarasick, D. W., Hoegger, B., Stubi, R., Schmidlin, F. J., Northam, T., Thompson, A. M., Witte, J. C., Boyd, I., and Posny, F.: Assessment of the performance of ECC-ozonesondes under quasi-flight conditions in the environmental simulation chamber: Insights from the Juelich Ozone Sonde Intercomparison Experiment (JOSIE), J. Geophys. Res. Atmos., 112, D19306, doi: 10.1029/2006JD007308, 2007.

Stehr, J. W., Ball, W. P., Dickerson, R. R., Doddridge, B. G., Piety, C. A., and Johnson, J. E.: Latitudinal gradients in O-3 and CO during INDOEX 1999, J. Geophys. Res. Atmos., 107, 8015, doi: 10.1029/2001JD000446, 2002.

Stohl, A.: Computation, accuracy and applications of trajectories A review and bibliography, Atmos. Environ., 32, 947-966, 1998.

Stohl, A. and Seibert, P.: Accuracy of trajectories as determined from the conservation of meteorological tracers, Q. J. Roy. Meteorol. Soc., 124, 1465-1484, 1998.

Stohl, A., Wotawa, G., Seibert, P., and Kromp-Kolb, H.: Interpolation Errors in Wind Fields as a Function of Spatial and Temporal Resolution and Their Impact on Different Types of Kinematic Trajectories, J. Appl. Meteorol. 34, 2149-2165, 1995.

Stohl, A., Forster, C., Frank, A., Seibert, P., and Wotawa, G.: Technical note: The Lagrangian particle dispersion model FLEXPART version 6.2, Atmos. Chem. Phys., 5, 2461-2474, 2005, http://www.atmos-chem-phys.net/5/2461/2005/.

Swap, R. J., Annegarn, H. J., Suttles, J. T., King, M. D., Platnick, S., Privette, J. L., and Scholes, R. J.: Africa burning: A thematic analysis of the Southern African Regional Science Initiative (SAFARI 2000), J. Geophys. Res. Atmos., 108, 8465, doi: 10.1029/2003JD003747, 2003.

Takegawa, N., Kondo, Y., Ko, M., Koike, M., Kita, K., Blake, D. R., Hu, W., Scott, C., Kawakami, S., Miyazaki, Y., Russell-Smith, J., and Ogawa, T.: Photochemical production of O-3 in biomass burning plumes in the boundary layer over northern Australia, Geophys. Res. Lett., 30, 10, doi:10.1029/2003GL017017, 2003.
Thompson, A. M.: The Oxidizing Capacity of the Earths Atmosphere - Probable Past and Future Changes, Science, 256, 1157 1165, 1992.

Thompson, A. M., Witte, J. C., Freiman, M. T., Phahlane, N. A., and Coetzee, G. J. R.: Lusaka, Zambia, during SAFARI-2000: Convergence of local and imported ozone pollution, Geophys. Res. Lett., 29, 1976, doi:10.1029/2002GL015399, 2002.

Thompson, A. M., Witte, J. C., Oltmans, S. J., and Schmidlin, F. J.: Shadoz - A tropical ozonesonde-radiosonde network for the atmospheric community, Bull. Am. Meteorol. Soc., 85, 1549 1564, 2004.

Ward, J. H.: Hierarchical Grouping to Optimize an Objective Function, Journal of the American Statistical Association, 58, 236244, 1963.

Watson, C. E., Fishman, J., and Reichle, H. G.: The Significance of Biomass Burning as a Source of Carbon-Monoxide and Ozone in the Southern-Hemisphere Tropics - a Satellite Analysis, J. Geophys. Res. Atmos., 95, 16443-16450, 1990.

Whiteman, C. D.: Observation of Thermally Developed Wind Systems in Mountainous Terrain, in: Atmospheric Processes over Complex Terrain, edited by: Blumen, W., 323, American Meteorological Society, Boston, Massachusetts, 1990.

Wooster, M. J., Roberts, G., Perry, G. L. W., and Kaufman, Y. J.: Retrieval of biomass combustion rates and totals from fire radiative power observations: FRP derivation and calibration relationships between biomass consumption and fire radiative energy release,J. Geophys. Res. Atmos., 110, D24311, doi: 10.1029/2005JD006318, 2005.

World Meteorological Organization: Global Atmosphere Watch (2008-2015), Strategic Plan, Tech. rep., World Meteorological Organization, 2007.

Yokelson, R. J., Bertschi, I. T., Christian, T. J., Hobbs, P. V., Ward, D. E., and Hao, W. M.: Trace gas measurements in nascent, aged, and cloud-processed smoke from African savanna fires by airborne Fourier transform infrared spectroscopy (AFTIR), J. Geophys. Res. Atmos., 108, 8478, doi:10.1029/2002JD002322, 2003.

Zellweger, C., Buchmann, B., Klausen, J., and Hofer, P.: System and Performance Audit for Surface Ozone, Global GAW Station Mt. Kenya, Tech. rep., Empa-WCC, 2002.

Zellweger, C., Klausen, J., and Buchmann, B.: System and Performance Audit for Surface Ozone an Carbon Monoxide at the Global GAW Station Mt. Kenya, Tech. rep., Empa-WCC, 2005.

Zhang, L., Jacob, D. J., Bowman, K. W., Logan, J. A., Turquety, S., Hudman, R. C., Li, Q. B., Beer, R., Worden, H. M., Worden, J. R., Rinsland, C. P., Kulawik, S. S., Lampel, M. C., Shephard, M. W., Fisher, B. M., Eldering, A., and Avery, M. A.: OzoneCO correlations determined by the TES satellite instrument in continental outflow regions, Geophys. Res. Lett., 33, L18804, doi:10.1029/2006GL026399, 2006. 